Florida International University FIU Digital Commons

FIU Electronic Theses and Dissertations

University Graduate School

3-29-1996

\title{
Making life choices : facilitating identity formation in young adults
}

Steven L. Berman

Florida International University

DOI: $10.25148 /$ etd.FI14051116

Follow this and additional works at: https://digitalcommons.fiu.edu/etd

Part of the Child Psychology Commons, and the Developmental Psychology Commons

\section{Recommended Citation}

Berman, Steven L., "Making life choices : facilitating identity formation in young adults" (1996). FIU Electronic Theses and Dissertations. 1766.

https://digitalcommons.fiu.edu/etd/1766

This work is brought to you for free and open access by the University Graduate School at FIU Digital Commons. It has been accepted for inclusion in FIU Electronic Theses and Dissertations by an authorized administrator of FIU Digital Commons. For more information, please contact dcc@fiu.edu. 
FLORTDA INTERNATIONAL UNIVERSITY

Miami, Florida

MAKING LIFE CHOICES:

FACIIITATING IDENTTTY FORMATION IN YOUNG ADULTS

A dissertation submitted in partial satisfaction of the requirements for the degree of

DOCTOR OF PHILOSOPHY

IN

PSYCHOLOGY

by

Steven L. Bexman

1996 
To: Dean Arthur W. Herriott

College of Arts and Sciences

This dissertation, written by Steven L. Berman, and entitled Making Life choices: Facilitating Identity Formation in Young Adults, having been approved in respect to style and intellectual content, is referred to you for judgement.

We have read this dissertation and recommend it to be approved.

Myrna Crabtree

Scott Fraser

Wendy Silverman

$\overline{\text { William Kurtines, Major Professor }}$

Date of Examination: March 29, 1996

The dissertation of Steven L. Berman is approved.

Dean Arthur W. Herriott College of Arts and Sciences

Dr. Richard L. Campbell

Dean of Graduate studies

Florida International University, 1996 
I dedicate this dissertation to ny wife Gloria and to my parents. Without their financial and emotional support the completion of this work would not have been possible. 
ACKNOWLEDGEMENTS

First, I would like to thank the members of my committee, Dr. Myrna crabtree, Dx. Scott Fraser, Dr. Wendy Silverman, and Dr. William Kurtines for their helpful comments and patience.

Next, I would like to thank my intake coordinators, Janice Granados and Carolyn Lorente.

Additionally, I would like to thank all of the people who helped me to conduct the interview assessments: Ondina Arrufat, Alan Berman, Ervin Briones, Janene Bussel1, Laura Ferrer, Janice Granados, Carolyn Lorente, Blanca Martell, Jennifer Rice, Jamie Schmaltz, Adriana Schwinghammer, and Liliana Wole.

An additional special thanks goes to those who were also workshop leaders: Ondina Arrufat, Alan Berman, Ervin Briones, Janene Bussell, Laura Ferrex, Carolyn Lorente, Jamie schmaltz, and William Kurtines.

In particular, I cannot adequately express my gratitude to Ondina Arrufat and carolyn Lorente who gave so much of their time and effort to support this project. Your support and friendship sustained me and will never be forgotten.

Finally, I must thank William Kurtines, my major professor, my mentor, my friend. It has been a privilege to work undex your guidance. 


\section{ABSTRACT OF THE DISSERTATION \\ MAKING EIE CHOICES: \\ TACILITATING IDENTIPY FORMATION IN YOUNG ADUETS \\ by \\ Steven L. Berman \\ Foxida International university, 1996 \\ Miami, Norida \\ professor}

This dissertation makes a contribution to the growing literature on identity formation by fomulating, implementing, and testing the effectiveness of a psychosocial intervention, the Making Life choices (MLC) Workshops, designed to facilitate the process of 1 identity formation. More specifically, the MIC Workshops were designed to foster the development and use of critical cognitive and communicative skilis and competencies in choosing and fulfiling tife goals and values. The MrC Workshops consist of a psychosocial group intervention that includes both didactic and group experiential exercises. The primary research guestion for this study concerned the effectiveness of the MLC Workhop relative to a control condition. Effectiveness was evaluated on two levels: skills development and reduction of distress. First, the effectiveness of MLC in costering the development of 
critical competencies was evaluated relative to a control condition, and no statistically significant differences were found. Second, the effectiveness of MLC in decreasing iffe distress was also evaluated relative to the control condition. While participants in the MLC workshop had no significant decrease in distress, they did have statistically significant improvement in life satisfaction in the Personal Domain. 
TABLE OF CONTENTS

CHAPTER

PAGE

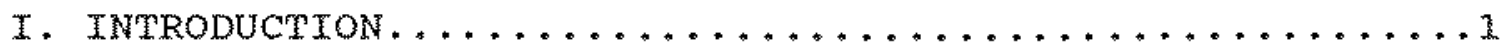

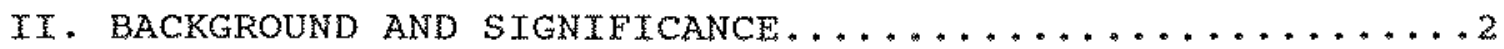

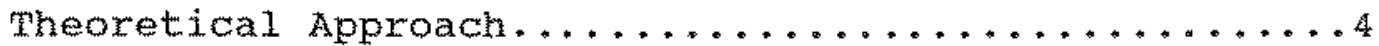

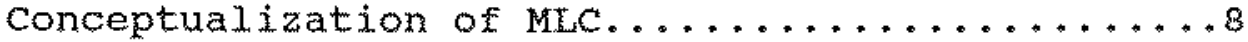

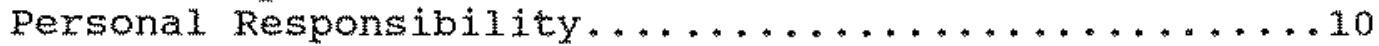

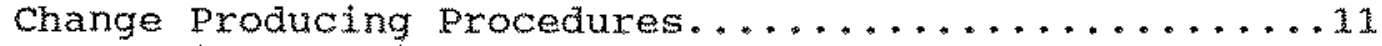

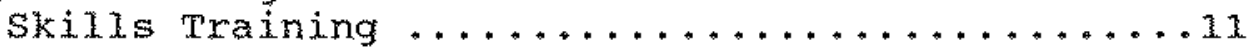

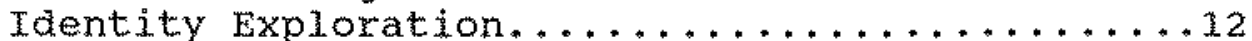

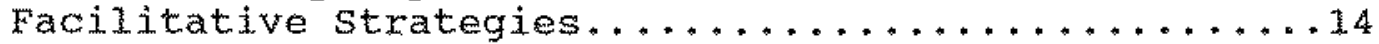

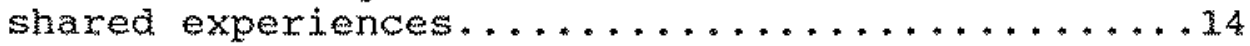

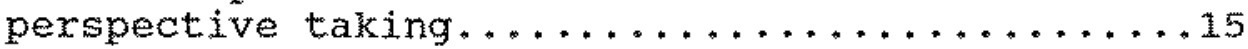

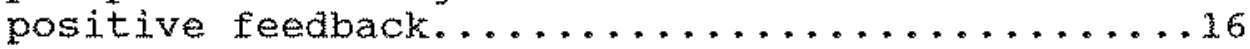

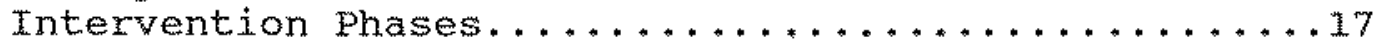

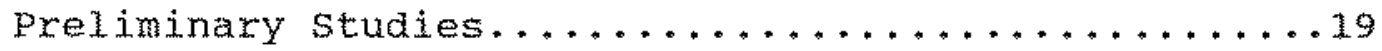

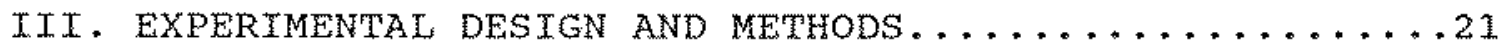

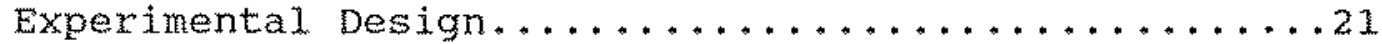

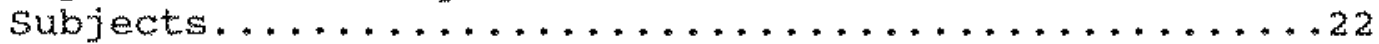

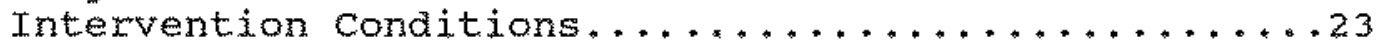

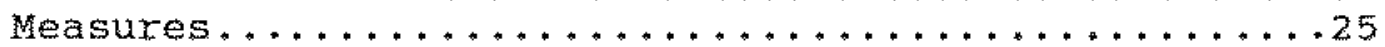

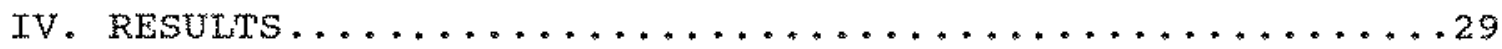

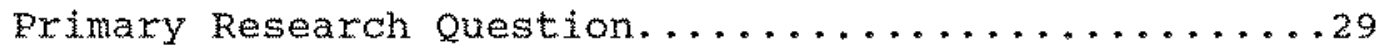

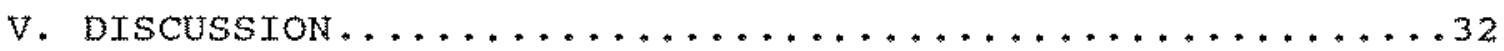

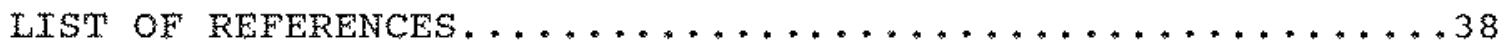

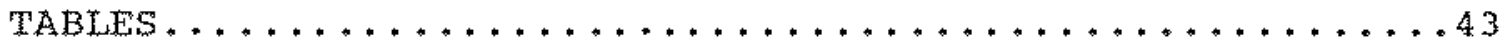

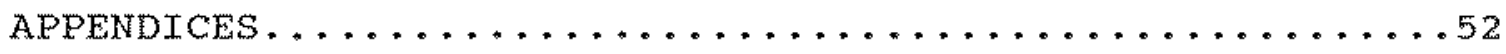

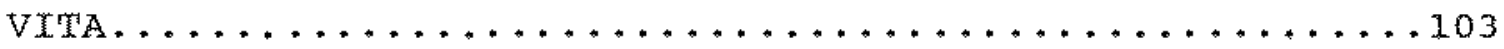




\section{LEST OF TABLES}

1. Means, Standara Deviations and F-ratios for pre to

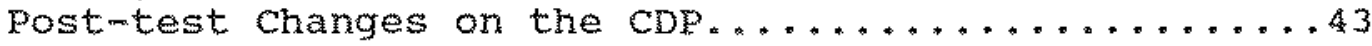

2. Means, Standard Deviations and Fratios for Pre to postutest changes on Satisfaction Ratings by Domain on

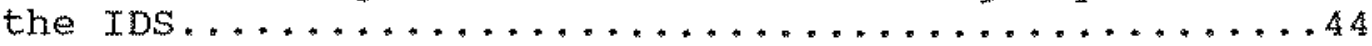

3. Means, Standard Deviations and F-ratios for pre to Post-test Changes on Distress Ratings by Domain on the

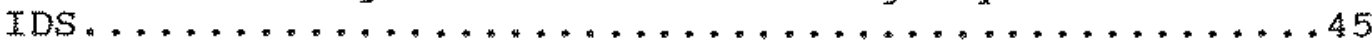

4. Means, Standaxd Deviations, Alphas, and Correlations, for Pre-test Subscales on the CDP.............46

5. Means, Standard Deviations, Alphas, and Correlations,

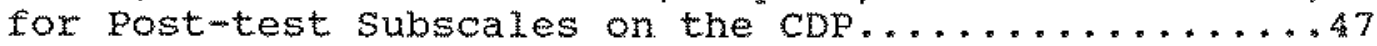

6. Means, Standard Deviations, Alphas, and Correlations, for Pre-test Satisfaction Subscales on the IDS.....48

7. Means, Standard Deviations, Alphas, and correlations, for Pre-west Distress Subscales on the IDS........49

8. Means, Standara Deviations, Alphas, and Correlations, for Post-test satisfaction subscales on the IDS....50

9. Means, Standard Deviations, Alphas, and Correlations, for Post-test Distress subscales on the IDS.......51 


\section{LIST OF APPENDICES}

A. Critical Decision Making and problem Solving scale -

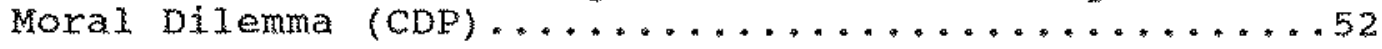

B. Identity Domain scale (IDS) ................64

c. Leader's Manual for Making tife Choices Work shop... 88 


\section{Introduction}

This dissertation provides a preliminary evaluation of the effectiveness of the Making life choices (MLC) Workshop, a psychosocial intervention that facilitates making the type of difficult ife choices that adolescents normatively experience at this developmental stage (e. 9 , choosing a career, making decisions about intimate relationships such as courtship and marriage, the adoption of political, religious, economic, etc. beliefs about the world). The MLC Workshop was designed to combine the most beneficial features of a group format with cognitive and behavioral procedures that have proven to be effective. The primary research question for this study concerned the effectiveness of MLC relative to a control condition. Efectiveness was evaluated on two levels: skills development and reduction of distress. First, the effectiveness of MLC in fostering the development of critical competencies was evaluated relative to a control condition. second, the effectiveness of MLC in reducing distress was evaluated relative to a control condition. The data analytic strategy involved repeated measures analysis of variance. An implementation manual is available for MLc, thereby rendering the modality replicable by other researchers. 


\section{Background and significance}

The stage in the life cycle called adolescence confronts the individual with a complex and difficult challenge (and responsibility), namely, that of choosing and fulfilling the goals and values that qive the individual's life direction and purpose. In the psychological literature this process has come to be called the formation of an identity. As modern society has become increasingly more complex, diverse, and pluralistic, making the life choices that define the individual's identity (and living up to the responsibility for these choices) has become increasingly more difficult (Erikson, 1968). As a consequence, for most youth in modern culture the transition to adulthood poses a formidable challenge, and many experience considerable distress as part of this transition. For some, the experience of distress becomes overwhelming and distupts the normal course of development rendering the individual dysfunctional. Indeed, the Diagnostic and Statistical Manual of Mental Disorders, third edition, revised (DSM-IIIR) (American Psychiatric Association, 1987): contains a diagnostic category for a disorder, termed Identity Disorder, whose essential feature is severe subjective distress regarding the inability to integrate aspects of the self into a relatively coherent and acceptable sense of self. As defined by DSM-III-R, an Identity Disorder 
encompasses uncertainty about a variety of issues relating to identity, including long-term goals, career choice, friendship patterns, sexual orientation and behavior, religious identification, moral value systems, and group loyalties. Thus, for many people the severity and pervasiveness of distress associated with the process of defining a sense of direction and purpose for their lives presents a serious problem that affects the quality of their lives.

The DSM-IV (American Psychiatric Association, 1994) has now reclassified Identity Disorder as Identity Problem and listed it under the heading of other Conditions That May Be a Focus of clinical Attention. This change reflects a recognition that the process of defining one's sense of identity is one of several normal and healthy developmental challenges of life, particularly at adolescence (Exikson, 1968). As a consequence, the experience of distress during this psychosocial crisis is to be expected. Although distress related to identity exploration is no longer considered a mental disorder, that does not mean that the distress cannot be severe and disruptive to normal functioning. Thus, although the DsM category for this type of distress has changed, the problem itself has not changed or gone away. In modern society, identity aistress still represents a serious problem for many young people, and the 
MLC Workshop seeks to help young people experiencing distress.

\section{Theoretical Approach}

The concept of identity used in this project draws on the work of Erikson. Erikson (1964) has described the experience of identity as rooted in the very core of one"s being. The concept of identity used in this project also araws, in general, on the large and growing literature that has emerged in the area (e.g., Adams, Bennion, \& Hugh, 1987; Adams, Fitch, \& Shea, 1979; Baker, 1971; Bronson, 1959: Grotevant \& Aams, 1984; Murray, 1964; Rasmussen, 1964; Simmons, 1970; Waterman, 1982; 1992), and the work of James Marcia (1966; 1980), in particular.

Marcia (1966), whose work has been among the most influential in the literature, conceptualizes identity fomation in tems of four statuses along a developmental continuum. The statuses are defined relative to the degree that the individual has made progress toward achieving a satisfactory identity. The formation of an identity is conceptualized as involving two basic dimensions, exploration and commitment. Exploration is the process by which the individual actively searches for a resolution to the issues of choosing the goals, roles, and beliefs about the world that provide the individual's life with direction and purpose as well as integration and conerence. 
Commitment represents a positive outcome of the process of exploration. If a commitment is made with respect to issues such as the selection of an occupation or career, gender role, friendship, group nembership, moral issues, religion, etc., an assured sense of self (pexsonal identity) is achieved. Identity confusion or diffusion results if there is not an active search for the resolution of these issues or if the individual is not able to consolidate available alternatives in a cohesive and consistent manner. Marcia's four identity statuses are thus defined with respect to the two dimensions of exploration and commitment. The four identity statuses are: a) diffusion, b) foreclosure, c) moratorium, and d) achievement.

The identity diffusion status is characterized by individuals who are not comitted to any particular goals, roles, or beliefs about the world and are not actively searching for them either. The identity foreclosure status is identified in individuals who lacked an identity crisis but are nevertheless comitted. Generally, these commitments represent those goals, roles, and beliefs about the world suggested by parental figures and are assumed without being questioned or examined and are therefore parental rather than self-determined. The moratorium status precedes identity achievement. The individuals in this status experience a "crisis" due to their active exploration 
or consideration of the different options but are not able to choose from the available alternatives or commit themselves. Finally, those individuals who are able to move beyond the moratorium status and are able to choose the goals, roles, and beliefs about the world that give their Iife purpose, coherence, and integration. The achievement status then is represented by individuals who have made a decision about what they want to do with their lives and are pursuing a course of action towards their commitments. Commitment involves making firm, unwavering decisions in areas of personal interest and engaging in appropriate implementing activities.

Like Marcia, this project considers the process of identity formation to be defined by the dimensions of exploration and commitment, and the development of MLC was undertaken as part of a program of research that seeks to help young people experiencing distress. The approach used for this program of research derives from a coconstructivist approach to human behavior and development: (Kurtines, Berman, Ittel, \& Williamson, 1995; Kurtines, 1984; 1987; 1994; Kurtines, Mayock, Pollard, Lanza and Car1o, 1991: Pollard, Kurtines, Carlo, Dancs, and Mayock, 3991). This perspective views the human species as a self- 
directed," goal oriented biopsychosocial organism that, 1ike other species, is confronted with the task of successfully adapting to continuously changing conditions. Human beings, however, not only respond to changes in their environment, they also have the capacity to shape and influence the conditions to which they respond. The human species is a biopsychosocial organism with complex, higher order cognitive and communicative capacities that enable them to engage in decision making and problem solving activities that affect the quality of their lives.

The Making Life Choices Workshop (MLC) draws on an ongoing program of research being conducted at the center

${ }^{1}$ there has been an increased interest in the concept of agency in the recent psychological literature. Moreover, as Waterman (1992) has pointed out, a number of the most recent developments regarding our understanding of agency-related concepts have been proposed by theorist in the behavioral tradition. For example, the concept of expectancies for locus of control (Lefcourt, 1982; Rotter, 1966) have been proposed by theorists identified with the behavioral tradition. More recently, Bandura (1982) made an important contribution to our understanding of the concept of agency with his work on selfefficacy. Self-efficacy refers to the belief that one can competently execute a particular behavior. According to Bandura, our perceptions, whether veridical or not, influence our choice of behaviors, our preparation for carrying then out, and our persistence at them in the face of obstacles. In this early work, Bandura was not explicit about whether choices based on perceptions of selfmefficacy entail volitional action. Rather, he presented the concept of self-efficacy in the context of the traditional social learning theory paradigm that external factors affect behavior. As Waterman (1992) has noted, however, in his most recent work Bandura (1989) he has extended our understanding of the concept of agency by explicitly endorsing a concept of freedom and human agency in terms of the exexcise of self-influm ence. 
for Child and Family Psychosocial Research. This program of research uses a pragmatic orientation in the development of interventions that target youth. This pragmatic contextualist orientation seeks to expand our scientific understanding of a wide range of problens in youth, and to use this knowledge to develop effective methods for alleviating the distress and suffering that these problems present. That is, this pragmatic contextualist orientation seeks to integrate and combine the most efficacious methods of prevention, assessment and intervention of psychosocial research, and to modify and adapt these methods for use with specific problems and populations.

\section{conceptualization of MLC.}

The effectiveness of the Making Iife Choices Workshop (MLC) in the treatment of identity distress associated with the uncertainty of making the type of difficult life choices that late adolescents normatively experience is evaluated in this dissertation. This work is part of a growing recognition of the need to develop effective interventions ${ }^{2}$

'In this work a distinction is made between psychosocial or psychoeducational interventions and psychothexapeutic interventions. Psychotherapeutic interventions are treatment interventions designed for use with patients or clients with diagnosable mental disorders (i.e., meet DSM-V criteria for a diagnostic category). Psychotherapeutic interventions are thus psychopathology based and designed for use with individuals with identifiable maladaptive modes of functioning. The aim of such interventions is to work with individuals to reduce or eliminate maladaptive modes of functioning and restore or return the 
with this population (Archer, 1994). The Making Life Choices workshop tested in this dissertation is a multifaceted intervention designed to be adaptable for use with a wide range of age populations (e.g., early adolescent identity distress, identity issues in midmife etc.), The multifaceted format of MLC is designed to combine the most beneficial features of a group format that uses cognitive and behavioral facilitative strategies for implementing the intervention's two primary change producing procedures: teaching/learning critical decision making and problem solving skills and fostering identity exploration.

When an intervention is to be evaluated, one critical feature that needs to be carefully specified is the conceptual basis of the treatment (Kazdin, 1988). The first part of this section will discuss the conceptualization of the issue of personal responsibility that provides the background for the implementation of the intervention's change producing procedures and facilitative strategies. This second section of this part will describe the rationale

\footnotetext{
2 (...continued)
}

individual to normal, adaptive modes of functioning. Psychosocial interventions, on the other hand, are not treatment interventions and are not designed for use with patients or clients with diagnosable mental aisorders. Psychosocial interventions are competency based and use skill development training designed for use with individuals with who are currently functioning at an adaptive level. The aim of such interventions is to work with individuals to increase the level of adaptive functioning, and to mode them beyond normal functioning to more enhanced levels of functioning. 
and conceptualization of the two key change producing procedures -- skill training and exploration. The third section will describe the intervention"s facilitative strategies -- shared experiences, perspective taking, and positive feedback. Although the components of MLC will be described separately in this section for purposes of explanation, they are conceptualiy intercelated and integrated for purposes of implementation.

\section{Rersonal Responsibility}

The conceptualization of the issue of personal responsibility described in this section draws on the existential pragmatic tradition in modern thought. From the existential tradition we adopt the view that human beings, unlike other things or objects in the world, are responsible for their decisions and actions, i.e., that human beings are responsible for their decisions and actions because they are self-directed agents capable of using complex cognitive and communicative decision making and problem solving skilks to make choices that affect the quality of their lives. From the pragmatic tradition we adopt a view of deciaing what is the right thing to do as a type of problem solving activity, i.e., a view that human beings can use these same decision making and problem solving activities in deciding what is the right thing to do. This existential-pragmatic tradition provides the foundation for our view that human beings not 
only have the type of cognitive and communicative problem solving and decision making capacities that enable them to make choices that acfect the quality of their lives, but also that they are responsible for their choice.

Therefore, the background introduction to the workshop exercises provides an overview of the concept of personal responsibility. The purpose of this overview is to educate the participants concerning personal responsibility and to "set the stage" for the use of the change producing procedures to foster skills development and identity exploration. The overview of personal responsibility thus stresses that although the purpose of the workshop is to teach skills in making life choices, it is the workshop participants who are ultimately responsible for the choices they make.

\section{Change producing procedures}

1) Skills Training. One of the key change producing procedures in MLC is that of training in the use of decision making and problem solving skilis. The utility of training in interpersonal problem solving has been documented in a variety of settings with diverse populations (Camp \& Bash, 1985; Spivack, Platt, Shure, 1976; spivack \& Shure, 1982). Training adolescents in interpersonal problem solving and social competence has also been adopted in most states (e.g., New York, New Jersey, Califormia, etc.) (Rotheram- 
Borus \& Wyche, 1994). The type of decision making and problem solving that will be used in this project draws on this work and includes exercises that target the development of generic problem solving skills.

More specifically, the generic problem solving skills Which the workshop focuses on are ones that have been identified in the literature. These include: identifying what the problem is, generating alternatives for solving the problem, and selecting the best alternative. The type of decision making and problen solving that will be taught in the workshops thus draws on previous work but extends it in two important ways. Fixst, it extends it by adding a "critical" thinking component, which makes it more useful for making aifficult life choices. The critical component includes exercises designed to facilitate the use of suspension of judgment and the use of critical examination. Second, critical decision making and problem solving has been adopted for use in making group decisions and is therefore useful in the context of a group format.

2) Identity Exploration. The second key change producing procedure in MLC is that of identity exploration. Exploration and comitment have become widely recognized in the 1iterature as key processes in the successful formation of an identity (Adams \& Fitch, 1982; Marcia, 1966, 1980; Waterman, 1992). As part of the process of the formation of 
an identity, the individual searches for, explores, and investigates alternative life roles, goals and values, actual as well as potential. The process of exploration enables the individual to identify ife roles, goals and values worthy of $\mathrm{his} / \mathrm{her}$ personal commitment. The process of naking a commitment to a particular set of life roles, goals and values defines the endpoint or outcome of the identity formation process. A key assumption of MLC is thus that exploration is the process by which alternative choices are surveyed, identified and evaluated and that a comitment to a particular choice(s) is the outcome of this process. An additional assumption of MLC is that the process of the formation of an identity is thus not a purely subjective process: it does not take place in a social vacuum. We choose the goals and values that provide the direction for our life (and we are responsible for our choices), but we do not choose them in isolation. Our decisions are made in the context of our relations with others, and our relations with others helps to define the quality of our personal life. The formation of an identity involves both the subjective construction and intersubjective comconstruction of life goals and values. The group format for MLC is therefore more than simply a useful and cost-effective format. Rather, as discussed next, group processes play an integral 
part in facilitating the process of skills development and exploration.

Facilitative strategies.

Because MLC uses a group format, the intervention makes available "natural" group processes that can help to facilitate the effects of the key change producing procedures. More specifically, MLC uses three facilitative strategies (e.g., shared experiences, perspective taking, and positive feedback) to fostex skills training and identity exploration. How we use each of these strategies in our intervention is described in subsequent sections.

a) shared experiences. The continuing and ongoing interactions among the group members contribute to the experience of group cohesion and trust. As a consequence, members of the group begin to feel more comfortable sharing life experiences related to personal life dilemas. The process of sharing experiences primarily facilitates the process of identity exploration. When one person discusses his/her life dilemas as part of the group exercises, the sharing of this experience serves to broaden the range of types of experiences to which individual members of the group are exposed. This, in turn, provides then with additional relevant information and alternatives as they explore their own life choices. The diversity of goals and values that emerge in the context of group discussion also 
exposes the individual members to a broader and more diverse arxay of alternatives as they explore life choices.

b) perspective taking. In MLC perspective taking is used to facilitate identity exploration. perspective taking involves adopting a point of view or "perspective" that is different from one's own point of view. As adolescents interact with peers who see the world differently, they begin to understand the limits of looking at the world from one perspective. piaget (1932/1965) suggests that peers have an important influence on diminishing one anothex's self-centered outlook because they interact as equals. A substantial body of evidence demonstrates that the behavior of weli-adjusted, competent youth is maintained in part by a number of social cognitive abilities, including social perspective taking and interpersonal problem solving (Enxight, Ganiere, Buss, Lapsley, \& Olson, 1983; Enxight, Olson, Ganiere, Lapsley, \& Buss, 1984). In MLC the perspective taking exercises $(e .9 .$, role play, switching roles, etc.) focus on taking alternative perspective for the Iife dilemmas that emerge in the group sessions. perspective taking is thus used to facilitate the exploration of other life alternatives in resolving life dilemmas.

In MLC perspective taking is also used to facilitate skills training as well as to facilitate the exploration of 
other life alternatives in resolving life dilemas. Because the MLC perspective taking exercises help participants develop decentering skills, the exercises facilitate the individual's distancing themselves from the limited range of alternatives available from a single perspective. Perspective taking thus facilitates generating alternatives for successfully resolving life dilemmas.

\section{c) positive feedback. positive feedback serves} primarily to facilitate skills training, although it will also be used to facilitate exploration. With regard to facilitating skills training, when a member of the group observes another group member successfully using one of the critical skills (e.9., critically examining one of the alternative life choices being considered) it provides the opportunity for positive modeling to occur. The successful use of the skill, in turn, provides the opportunity for peer reinforcement from the other members of the group and reinforcement from the group facilitator. The group can also provide corrective or instructive peer and facilitator feedback, e.g., as when an adolescent shares with the others in the group his/her concern about a particular choice or decision. The group also facilitates social comparison processes, $\dot{i}$.e., the presence of other's in the group facilitate the youth's evaluation of his/her decisions and actions relative to consensual standards of appropriate 
behavior. For example, hearing about how other adolescents handle situations involving different life dilemas contributes to the adolescent's understanding how to handle his/her own life dilemmas.

\section{Intervention Phases.}

The specific phases in which the components of MLC were implemented are described next, followed by a summary of the sessions.

A preliminary manual for the intervention was developed to standardize the general content of each session (see Appendix).

MLC consisted of five sessions. Each session was 90 minutes in length, and took place twice a week for three consecutive weeks. The first session provided an introduction to the overall rationale for the program and skill practice with a hypothetical dilemma. In the second and third sessions, the skills were reviewed and applied to a personal real life dilemma for each group member. The fourth session involved review and application of the skills to a second real Iife dilemma for each group member. The fifth session focussed on termination, and was used as follow up to continue practicing the skills in reference to personal life dilemas.

session 1: Group introduction and discussion of the workshop goals. Presentation of workshop intervention 
rationale, emphasize the importance of practice and skills training, benefits of group process and the importance of sharing experiences, perspective taking, and receiving feedback. Discuss the concepts of Making Life choices and Responsibility. Explain the steps in problem solving and the role of critical thinking and discussion in decision making. Outline the concept of I.C.E. as a tool for problem

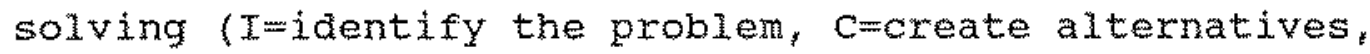
E=evaluate the alternatives) Explain group "rules", and practice using critical and problem solving skills using a hypothetical dilemma.

session 2: Review treatment rationale and goals, and related concepts discussed in previous session. Have each subject identify the specific personal life choice dilema that will be addressed. Group discusses each dilema using the steps to problem solving and providing positive feedback for the use of critical skills. Group members encouraged to share experiences and take varying perspectives to enhance the process of exploration.

session 3: Review treatment rationale and goals, and related concepts discussed in previous session. Have each subject continue to work on their specific personal life choice dilemma. Group discusses each dilemma using the steps to problem solving and providing positive feedback for the use of critical skills. Group members encouraged to 
share experiences and take varying perspectives to enhance the process of exploration.

session 4: Review treatment rationale and goals, and related concepts discussed in previous session. Have each subject identify a second specific personal ilfe choice dilemma that will be addressed. Group discusses each dilema using the steps to problem solving and providing positive feedback for the use of critical skills. Group members encouraged to share experiences and take varying perspectives to enhance the process of exploration.

Session 5: Review concepts. Continue to practice decision making and problem solving skills by further discussion of personal life choice dilemmas from previous session. Review progress, the need for continued practice on their own, and termination. Complete workshop Evaluation Form and schedule Follow up assessments.

\section{A. Preliminary studies}

A preliminary pilot study was conducted in order to develop and refine a preliminary form of MLC for use with the target population. The process of developing and refining MLC required two phases.

Phase 1. The first phase involved the development of a set of preliminary lessons and workbook exercises. For this phase a series of lessons were drafted for critique by the workshop research group. The purpose of this procedure was 
to insure as far as possible that the material in the lessons represented the content of the skills that were the taxget of the skills training component. An additional aim of this procedure was to construct an administrative format appropriate for a workhop in terms of both level and style. variations in content and administration formats for the lessons were constructed and critiqued by the members of the workshop research group. The content of the cxitiques involved such basic considerations as 1) how much of the workshop should be didactic versus experiential, 2) what role should the facilitator play in the group process, and 3) the use of hypothetical versus "real ife" dilemmas.

Phase 2. The second phase of the development of MLC involved pilot testing the workshop. The subjects for this phase $(\mathrm{N}=10)$ consisted of late adolescent college students. The subjects participated in two workshops conducted by two different facilitators. Both workshop were videotaped for analysis and critique. In addition, subjects in the workshops were asked to participate in an additional session after the end of the final session. The purpose of the post workshop session was to provide opportunity for extensive debriefing and feedback from the subjects in relation to their evaluation of the workshop sessions.

Although the number of subjects in the pilot study was not large enough to allow the collection of outcome data, 
the results of the debriefing sessions indicated that participants consider the workshops a worthwhile expexience and thought that they had learned some skills that might help them in the future.

The results of the pilot study was used to further develop and refine the Study Guide and Workbook as well as the administrative format of the MLC. This revised version of the MLC is the version that was more extensively pilot tested in this study.

Experimental Design and Methods*

\section{Experimental Design.}

The research design for this study was a pre-post experimental design with a control group designed to control for format (group versus individual) and content (critical problem solving versus creative problem solving). The design consisted of one factor (intervention mode) with two cells: Condition I (Making Life Choices Workshop; MLC) and Condition 2 (Placebo Control; pc). participants were assigned to workshop groups (MLC) on the basis of their schedule of availability. Those who's schedules did not fit with the assigned group times were placed in the control group $(\mathrm{PC})$. (see subject section). Pre and post assessments were conducted. The design can be illustrated as follows: 


\section{Experimental Design}

$$
\text { Pre-Test Intervention Post-Test }
$$

$\begin{array}{llll}\text { MLC Treatment } & 0 & x_{1} & 0 \\ \text { PC control } & 0 & x_{2} & 0\end{array}$

Note: o=observation (Measurement), $x=$ Intervention subjects.

A total of 43 late adolescent college students participated in this study. Twenty-five students participated in one of six workshop groups. Group sizes varied from three to six members. Each group had a different group leader and met together for five consecutive 90 minute sessions. Eighteen othex students were assigned to a placebo control condition. These participants did not meet in groups, but rather, individually completed a series of workbook exercises aimed at developing cxeative problemsolving skills.

Subject Recruitment. Students were offered extra credit in their psychology class in exchange for participation in this study.

subject selection. Because this is a psychosocial intervention rather than a psychotherapeutic intervention, all subjects volunteering to participate were admitted to the study *

Inclusion criteria. To be included in the study the subjects had to express a wilingness to attend and complete 
al1 of the assessment and treatment sessions. They must have been willing to provide informed consent and to be videotaped during the assessment and workshop sessions.

Exclusion criteria. The criteria for exclusion was that any subject who reported thoughts of hurting themselves or others on any of the measures or during any of the sessions or during any contact with the lab would be excluded from participation in the intervention. In addition, any subject who gave any obvious indication of psychopathology (e.g., thought disorders, symptoms of major depression, etc.) would also be excluded from participation. Subjects who meet either criteria would be handled according to the standard lab policy. The standard lab policy is for the subject to be referred to faculty lab supervisor. The faculty lab supervisor is responsible for making the appropriate referral for evaluation and services. While several students were referred to faculty lab supervisor for furthex evaluation, none were deemed necessary to exclude. Intervention conditions. Prior to assessment, subjects were provided with an informed consent form.

condition 1 (MLC). The Making ifife Choices workshop Experimental condition. As noted above, MLC is a cognitivebehavioral intervention to be used in a group format with late adolescent college students who are seeking help in making ife choices. MLC includes skills training and 
identity exploration, key therapeutic ingxedients for successful life dilema resolution. It also inoludes group processes that can facilitate treatment that are not available in the individual approach. These processes include: shared experiences; perspective taking, and positive feedback. MLC consists of five 90 minute sessions. Condition $2(\mathrm{CC})$. The control condition (cc). Because there have been no experimental outcome studies of MLc, the first step is to establish its efficacy. Therefore, the study compares MLC to an individual creative problem solving comparison control condition designed to control for many challenges to the internal validity of research designs such as history, maturation, cohort effects, etc. Individual creative problem solving was also selected to serve as the comparison condition because it has the additional advantage of providing all students with an opportunity to participate in an established positive learning expexience with similar content but with a different focus and format than the experimental condition, which is not offered by other types of control conditions (e.9., placebo control with no intervention). Participants in this condition individually completed a number of paper and pencil exercises from a workbook aimed at developing creative problen solving skills (Ainsworth-Land and Fletcher, 1979). Completion of all 
Completion of all exercises took approximately six hours on the average, spread over several sessions.

subjects were pre-tested before participating in one of the two conditions, and post-tested with the same outcome evaluation measures at the end of the intervention interval.

Intervention Integrity: A necessary condition for making valid conclusions on the basis of the results of intervention outcome investigation is evidence that the intervention procedures were administered in an appropriate fashion (Kazdin, 1980; Yeaton \& Sechrest, 1981). The purpose of the intervention integrity check is to ensure the standardized delivery of the intervention protocols. Therefore, the integrity of the administration of intervention procedures was assessed by means of judges" rating of the content of periodic video taped spot checks of the workshop sessions. To avoid the possibility that the periodic spot checks may alter the way the sessions are conducted, all intervention and control sessions were routinely video tape recorded (with participants' written consent in advance of the intervention). Twenty-five percent of these session tapes were randomily selected for assessments of intervention integrity.

Measures. This section describes the two measures used to evaluate outcome in this study: A) Skills Development 
Measure, and B) Life Satisfaction. The measures were obtained in pre and post assessment sessions.

A) Skilis Development Measure

Cxitical Decision Making and Problem Solving scale (CDP) The CDP consists of a two part, ten page protocol administered using an interview format. The test stimuli consist of six situations involving fictional characters (Hobbits) confronted with hypothetical moral dilemas. All six situations present the same type of "dilemma" a conflict between a prima facie moral obligation (e.9., telling the truth, keeping a promise, etc.) and a negative consequence for one of the characters. The "problem" the dilemmas present is thus one of conflicting moral obligations, and the subject has to decide which of the alternatives is the right thing to do.

The CDP is made up of two parts, the critical Thinking Subscale and the critical Discussion subscale. The critical Thinking Subscale is designed to elicit "cognitive" decision making and problem solving operations and actions. It is administered as a "standardized" interview, and the dilemas are presented as an individual decision making or problem solving situation (i.e., the subject has to decide what to do). The interviewer elicits the subject's account of his/her choice, and the subject's responses represented in the narrative account are coded for the categories of 
decision making and problem solving operations and actions the subject uses.

The Critical Discussion subscale is designed to elicit "Communicative" decision making and problem solving operations and actions. It is administered as an "interactive" interview, and the dilemmas are presented as a shared decision making or problem solving situation (i.e., the subject and the interviewer have to try to agree about what to do). The interviewer engages the subject in a discussion or dialogue involving his/her choice, and the subject's responses represented in the discussion are coded for the categories of decision making and problem solving operations and actions the subject uses.

The CDP is coded for two basic types of cognitive and commuicative operations and actions: Entertainments and Challenges. The CDP yields two quantitative scores: a score for critical Thinking and a score for critical Discussion. The critical Thinking Score is derived by suming the number of entertainments used across all four of the critical thinking dilemmas. The cxitical Discussion score is derived by calculating a difference score between Entertainments and challenges. A person who uses approximately equal numbers of entertaiments and challenges is scored as "critical". 


\section{B) Life Satisfaction}

Identity Domain Scale (IDS) The IDS consists of a self-report questionnaire that can be group administered. The measure asks subjects to report specific issues and general satisfaction in three domains of their life: personal development, interpersonal development, and world views. Each domain is further divided into three content areas (personal development: career goals, sense of self, long-term Iife goals; interpersonal development: friendships, group involvement, gender/sexuality issues; world view: religion, morality, politics). The questionnaire asks subjects to provide an open ended written description of both good or positive and distressful or troublesome experiences in each of the nine content areas. For each of the positive and troublesome experiences, the subject is also asked to provide a 5 point Likert description of how positive or troublesome that experience is for their life.

The IDS yields two sets of quantitive scores. The IDS is scored for nine content Area Satisfaction scores which consist of the satisfaction rating for each of the nine content areas, and three Identity Domain Satisfaction scores which consists of the average of the satisfaction ratings within each of the three identity domains. The IDS is also scored for nine content Area Distress scores which consist 
of the distress rating for each of the nine content areas, and three Identity Domain Distress scores which consists of the average of the distress ratings within each of the three identity domains.

\section{RESULTS}

This section operationalizes the tests for the hypotheses to be tested through the identification and specification of the dependent variables (outcome measures), statistical test(s), and corresponding significance level(s) for the rejection of the corresponding null hypotheses.

Primary Research question. The primary research question for this study concerned the general effectiveness of MLC relative to the control condition. Effectiveness was evaluated on two levels: skills development and life satisfaction. First, the effectiveness of MLC in improving skills development was evaluated relative to the control condition. Second, the effectiveness of MLC in improving Iife satisfaction was evaluated relative to the control condition.

Hypothesis 1: MLC subjects will demonstrate significant improvement in the development of critical decision naking and problem solving skills as measured by improvement in Critical Thinking scores and improvement in critical Discussion scores on the CDP relative to the control condition. 
Hypothesis 2: MLC subjects will demonstrate a significant increase in life satisfaction as measured by the three Identity Domain Satisfaction scores of the IDS (Personal Development, Interpersonal Development, and World view) and a significant decrease in life distress as measured by the three Identity Donain Distress scores of the Ios (Personal Development, Interpersonal Development, and World view) relative to the control condition.

The statistical analyses used to test Hypotheses 1 and 2 consisted of Repeated Measures Analyses of Variance. The analyses were specified as a mixed design (between and within) where Time (pre, post) was the within group (repeated) factor and Condition (Experimental versus Control) was the between group factor. Each hypothesis was tested separately. The dependent variables for Hypothesis 1 consisted of the critical Thinking scores and critical Discussion scores from the CDP. The dependent variables for Hypothesis 2 consisted of the three Identity Domain Satisfaction scores and the three Identity Domain Distress scores of the IDS.

The first set of ANOVAs focused on critical thinking and discussion scores as measured by the CDP. Table 1 presents the results of these analyses, and the findings are described next. As can be seen in table 1, there were no significant interaction effects for any of the critical 
thinking and discussion scores. The only scoke that even came close to reaching statistical sigrificance was the critical thinking score. on this score, the experimental group means showed improvement from pre to post test, as predicted in hypothesis 1 , while the control group means showed a decrease in critical thinking.

The second set of ANovas focused on identity satisfaction as measured by the IDS. Table 2 presents the results of these analyses, and the findings are described next. As can be seen in Table 2, the only significant interaction effect for life satisfaction was in the Personal Domain, and yielded the results predicted in hypothesis 2 . In this domain, the experimental group means showed improvement from pre to post test while the control group means actualiy showed a slight decrease in satisfaction over time, $\underline{F}(1,41)=7.00, p=.012$.

The third set of ANOVAs focused on identity distress as measured by the IDS. Table 3 presents the results of these analyses, and the findings are described next. As can be seen in Table 3 , the only significant interaction effect for identity distress was in the Interpersonal Domain, which ran counter to prediction. In this domain, the experimental group means showed improvement from pre to post test with a slight decrease in distress score, however, the control 
group means showed a greater decrease in distress over time, $\mathrm{E}(1,37)=4.61, \mathrm{p}=.038$.

\section{DISCUSSION}

This study provided a preliminary evaluation of the effectiveness of the Making Life Choices (MLC) Workshop, a psychosocial intervention to facilitate making the type of difficult life choices that adolescents face. The results provided limited support for the efficacy of the workshops. The result from the participants' evaluation of the workshops indicated that they not only responded enthusiasticaliy to the content of the workshop but also considered it a positive growth experience. on the evaluation form many indicated that the sessions were applicable to real Iife problems, and that they would have liked to have had more sessions. Finally, the results of the study also indicated a number of potential ways in which the workshop might be improved.

This study provided the first full scale implementation of the workshop, a short, time-limited intervention that used inexperienced facilitators. Moreover, the intervention seeks both to enhance skills development and modify subjective satisfaction and distress. In this context, it is disappointing but not very surprising that the workshop had limited success in enhancing skilis development. 
The results, however, point to some potentially useful directions. Enhancing skills development, particularly in areas as complex as critical thinking and critical discussion, is a challenging task. Thus, although the differences in critical thinking score means failed to reach statistical significance, the fact that they approached significance $(i . e,, p=.06)$ suggests that the workshops are having some positive effect. If future research replicates the lack of significant positive effects, it may indicate that significant change may require a greater exposure to the skills component of the workshop and/or a longer duration of time of exposure (i.e., a greater number of sessions). In addition, it may also be necessary to focus on increasing the potency of the workshops in regard to increasing the development and use of critical thinking skills among workshop participants.

The change in critical discussion is more problematic, but there are a number of possible explanations for the lack of significant improvement on critical discussion scores. First of all, while scoring the protocols it became apparent that not all interviewers were consistent in their interviewing style. The measure requires the interviewer to exactly match each of the participant responses for content and style in a mock debate. This is a particularly difficult skill that requires a good deal of training. The 
reliability and validity of the measure is dependent upon the consistency of the interviewers. Review of the videotaped interviews suggest that any future study must first focus on a more intensive training of interviewers to insure the accuracy of the results. of course, the other possibility is that the lack of significant change in regard to critical discussion is less a reflection on the reliability and validity of the measure than on the potency of the workshop. Increasing the dispositional use of these skilis may require an even more intensive treatment than increasing the dispositional use of critical thinking ski11s. As noted, perhaps five sessions is insufficient to achieve the desired gain. Future research may focus on increasing the number of sessions of this workshop.

The most promising results were obtained with respect to modifying subjective satisfaction. The workshops were effective in significantly increasing scores in the Personal Domain, although not the other two domains. This is consistent with the participants" positive response to the content and process of the workshops.

That the improvement in satisfaction scores was limited to the Personal Domain might be due to the fact that most participants chose to discuss issues related to that domain, e.g. Iife and career goals. Those that wanted to work on interpersonal issues had the option of choosing an 
alternative workshop (Making Relationship Work) also run at the same lab. Therefore, there were very few subjects in the Making Life Choices workshops who were working on dilemmas in the Interpersonal Domain, hence changes in satisfaction in this domain would not be expected. The World View Domain concerns areas such as religion, politics, and morality. There were virtually no participants that chose to work on issues in this domain, hence, changes in satisfaction in this domain would also not be expected. Perhaps this emphasis on career decisions over philosophical dilemmas is refiective of the priorities of today's college youth.

The change in distress was less positive. While the workshops were successful in improving life satisfaction in the personal domain, there was no significant reduction in identity distress in any domain for the workshop participants. There are a number of possible explanations for the lack of significant improvement in subjective distress.

First, there is the issue of subject recruitment. The original design of the study used in the pilot testing for this dissertation, targeted self-referred individuals that were experiencing subjective distress over making difficult Iife choices. Pilot data on these participants indicated that the workshops were resulting in a slight, although not 
statistically significant, increase in distress. As mentioned earlier, this period of self discovery can be a very painful process, and perhaps focussing on these unresolved issues highlighted the feellngs of distress. Hopefully, the continued use of critical thinking and discussion skills would ultimately lead to the resolution of the issues and a concomitant reduction in distress. Despite the slight increase in distress, participants still evaluated the workshops very favorably and dropout from the groups was not a problem. However, dropout was a large problem from the waitlist. While recruitment strategies were successful in achieving a small but steady flow of self-referrals, matching these people together in terms of schedules of availability in order to form groups became very difficult. Average time on the waitlist became so extraordinarily long, that it raised ethical considerations. Since the workshops were aimed at developing skills in order to increase identity satisfaction as well as to relieve distress, a new strategy was adopted. By recruiting from classrooms with the incentive of extra credit, the intervention no longer specifically targeted distressed individuals. Considering that the participants in this study were not necessarily distressed when they volunteered to participate, it seems logical that the benefits were 
found more in the area of improved satisfaction, rather than a decrease in distress.

That the control group displayed significantly more reduction in interpersonal distress than the control group was rather surprising when considering the fact that the control participants were working on individual assignments while the workshop participants worked in groups. Perhaps these results can best be explained by the fact that the IDS displays much higher test-retest reliability for the satisfaction scores than it does for the distress scores (Schmaltz, 1995). Future research might focus on replicating this study to determine if these findings in relation to the interpersonal domain can be consistently documented or if they were merely an expression of the lower reliability. This finding also highlights the need to improve the quality of the measure in this regard.

In summary, this study provided a preliminary evaluation of the effectiveness of the Making tife choices Workshop. The results provided limited but promising support for the efficacy of the workshops. It also suggested the need for further research aimed at refining the workshop in order to further enhance its effectiveness and refining the measures to more accurately evaluate its effectiveness. 


\section{R.}

Adams, G. R., Bennion, L. D., \& Huh, K. (1987). A

revision of the extended version of the objective measure of ego identity status: An identity instrument for use with 3ate adolescents. Ioumal of Adolescent Research, 1, 183198.

Adams, G.R., Fitch, I., \& Shea, S.A. (1979). Toward the development of an objective measure of ego-identity status. Journal of Xouth and Adolescence, $8,223-238$.

Ainsworth-Land, v. \& Fletcher, N. (1979). Making waves with creative problem-solving. Burfalo, NY: D.0.K. Archer, S. L. (Ed.). (1994). Interventions for adolescent identity development. Thousand Oaks, CA: Sage.

American Psychiatric Association. (1987). Diagnostic and statistical manual of mental disorders (3rd ed., revised). Washington, DC: Author.

American Psychiatric Association. (1994). Diagnostic and statistical manual of mental disorders (4th ed.). Washington, DC: Author.

Baker, F. (1971). Measures of ego identity: A multitrait multimethod validation. Educational and Psychology Measurement, 31, 165-173.

Bronson, G.W. (1959). Identity diffusion in late adolescence. Journal of Abnormal and Social Psychology, 59, $414-417$. 
Camp, B. W. B Bash, M. S* (1985), Think aloud:

Increasing social and cognitive skill - a problem-solving program for children. Champaign, IL: Research Press.

Enright, R. D., Ganiere, D. M., Buss, R. R., Lapsley, D. K., \& olson, L. M. (1983). Promoting identity development in adolescents. Joumal of Farly Adolescence, $3(3), 247-255$. Enright, R. D., Olson, L. M., Ganiere, D., Lapsley, D. K*, \& Buss, R. R. (1984). A clinical model for enhancing adolescent ego identity. Journal of adolescence, $7 x$ 119-130. Erikson, E. H. (1964). Insight and responsibility. New York: Norton.

Exikson, E. H. (1968). Identity, youth and crisis. New York: Norton.

Grotevant, H.D. \& Adams, G.R. (1984)* Development of an objective measure to assess ego identity in adolescence: Validation and replication. Journal of Youth and Adolescence, $13,419-438$.

Kazdin, A. E. (1980). Research design in clinical psychology. New York: Harper \& Row.

Kazdin, A. E. (1988). Child Psychotherapy: Developing and identifying effective treatments. New york: Pergammon. 
Kurtines, W. (1984). Moral behavior as rule governed behavior: A psychosocial role theoretical approach to moral behavior and development. In $W$. Kurtines \& J. I. Gewirtz (Eds.), Morality, moral behaviox and motal development. New York: John Wiley \& Sons, 303-324.

Kurtines, W. (2987). Soctomoral behavior and development from a rule governed perspective: Psychosocial theory as a nomotic science. In W. Kurtines \& J. L. Gewirtz (Eds.), Moral development through social interaction. New York: John Wiley \& Sons, 149-194.

Kurtines, w. (1994). Human behavior and development: A co-constructivist perspective. Unpublished Manuscript.

Kurtines, W. M., Berman, S. L., Ittel, A., \& Williamson, S. (1995). Moral development: A coconstructivist perspective. In $W$. W. Kurtines \& J. L. Gewirtz (Eds.), Moral development: An introduction. Boston: Aliyn \& Bacon.

Kurtines, W., Mayock, E., Pollard, S., Lanza, T., \& Carlo, G. (1991). Social and moral development from the perspective of psychosocial theory. In W. M. Kurtines \& J. L. Gewirtz (Eds.), Handbook of moral behayior and development, vol. 1. Hillsdale, New Jersey: Lawrence Erlbaum Associates, $303-333$. 
Marcia, J. E. (1966), Development and validation of ego identity status. Journal of personality and social psychology, $3(5), 551-558$.

Marcia, J. E. (1980), Identity in adolescence. In J. Adleson (Ed.), Handbook of adolescent psychology. New York: wiley.

Murray, J.B. (1964). The identity image of college students. Psychological Reports, 14, 267-271.

Piaget, J. (1932/1965). The moral fudgment of the child. (M. Gabain, Trans.), New York: Free Press. (Originaliy published 1932).

Pollard, S., Kurtines, W., Carlo, G., Dancs, M., \& Mayock, E. (1991). Moral education from the perspective of psychosocial Theory. In W. M. Kurtines \& J. L. Gewirtz (Eds.), Handbook of moral behavior and development, vol. 3 . Hillsdale, New Jersey: Lawrence Erlbaum Associates, 289-315. Rasmussen, J.E. (1964), The relationship of ego identity to psychosocial efrectiveness. Psychological Reports, 15, 815-825.

Rothexam-Borus, M. J. \& Wyche, K. F. (1994), Ethric differences in identity development in the united states. In S. L. Archer, (Ed.), Interventions for adolescent identity development. (pp. 62-83). Thousand oaks, CA: Sage. 
Schmaltz, J. (1995). Mapping identity domains. Unpublished mastex"s thesis. Department of Psychology. Florida International Universicy, Miami, FL.

Simmons, D.D. (1970). Development of an objective measure of identity achievement status. I. Project. Persona 1. Assess., 34, 241-244.

Spivack, G., Platt, J. J*, shure, M. B. (1976). The problem-solving approach to adjustment. San Francisco: Jossey-Bass.

Spivack, G., \& Shure, M. B. (1982). The cognition of social adjustment: Interpersonal cognitive problem-solving and thinking. In B. B. Lahey, \& A. E. Kazdin (Eds.), Advances in clinical psychology (vol. 5). (pp. 323-372). New York: Plenum.

Waterman, A. S. (1982). Identity development from adolescence to adulthood: An extension of theory and a review of research. Developmental Psychology, 18, 341-358. Waterman, A. S. (1992). Identity as an aspect of optimal psychological functioning. In G. R. Adams, T. P. Gullotta, \& R. Montemayor (Eds.), Adolescent identity fomation. (pp, 50-72). Newbury Park, CA: Sage.

Yeaton, W. H. \& Sechrest, L. (1981). Critical

dimensions in the choice and maintenance of successful treatments: Strength, integrity, and effectiveness. Journal of Consulting and clinical Psychology, 49, 156-167. 
Table 1

Means ${ }^{3}$. Standara Deviations and r-ratios for pre to Posttest changes on the CDP.

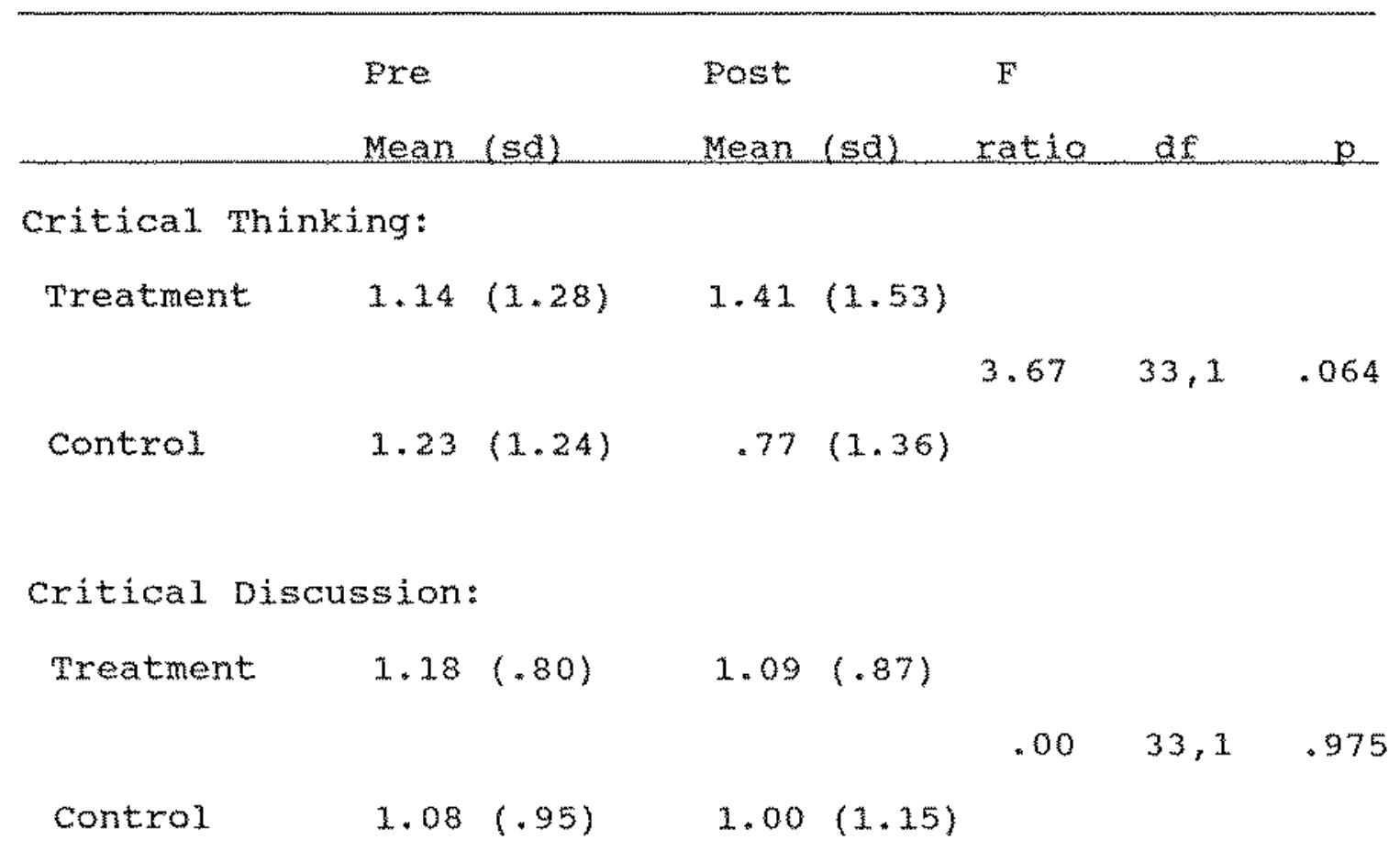

3 There are four critical Thinking dilemmas. Subject xesponses to each dilemma are scored as "critical" or "not critical". The number of dilemmas (i.e., 0 to 4) in wich the subject responses were scored as "critical" is the critical Thinking score. There are also four Critical Discussion dilemmas. Subject responses to each of these dilemmas are also scored as "critical" or "not critical". The numbex of dilemas (1.e., 0 to 4) in which the subject responses were scored as "critical" is the critical Discussion score. 
Table 2

Means, Standara Deviations and Ematios for Pre to Postatest Changes on Satisfaction Ratings by Domain on the IDS.

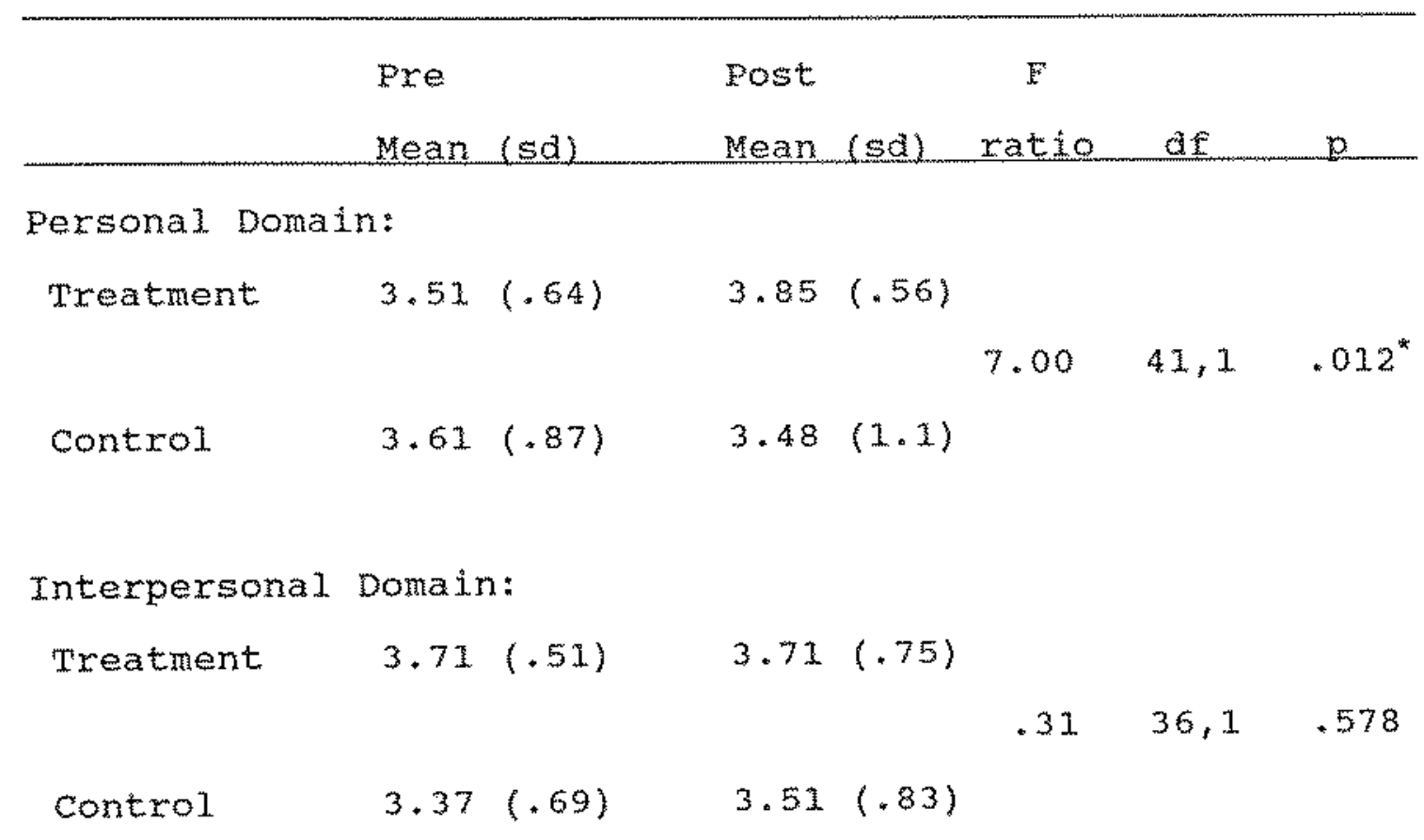

World View Domain:

$\begin{array}{llllll}\text { Treatment } & 3.57(.87) & 3.65(.81) & & \\ & & & & & \\ & & & & & \\ \text { control } & 3.30 & (.52) & 3.31(.74) & & \end{array}$

overall satisfaction:

\begin{tabular}{|c|c|c|c|c|c|c|c|}
\hline \multirow[t]{2}{*}{ Treatment } & 3.64 & $(.48)$ & 3.76 & $(.60)$ & \multirow[b]{2}{*}{.89} & \multirow[b]{2}{*}{35,1} & \multirow[b]{2}{*}{.352} \\
\hline & & & & & & & \\
\hline control & 3.43 & $(.55)$ & 3.43 & $(.84)$ & & & \\
\hline
\end{tabular}

4 Satisfaction Ratings range from 1 to 5 on a Iisert Scale. 
Table 3

Means, standard Deviations and F-ratios for Pre to postmtest Changes on Distress Ratings ${ }^{5}$ by Domain on the IDS.

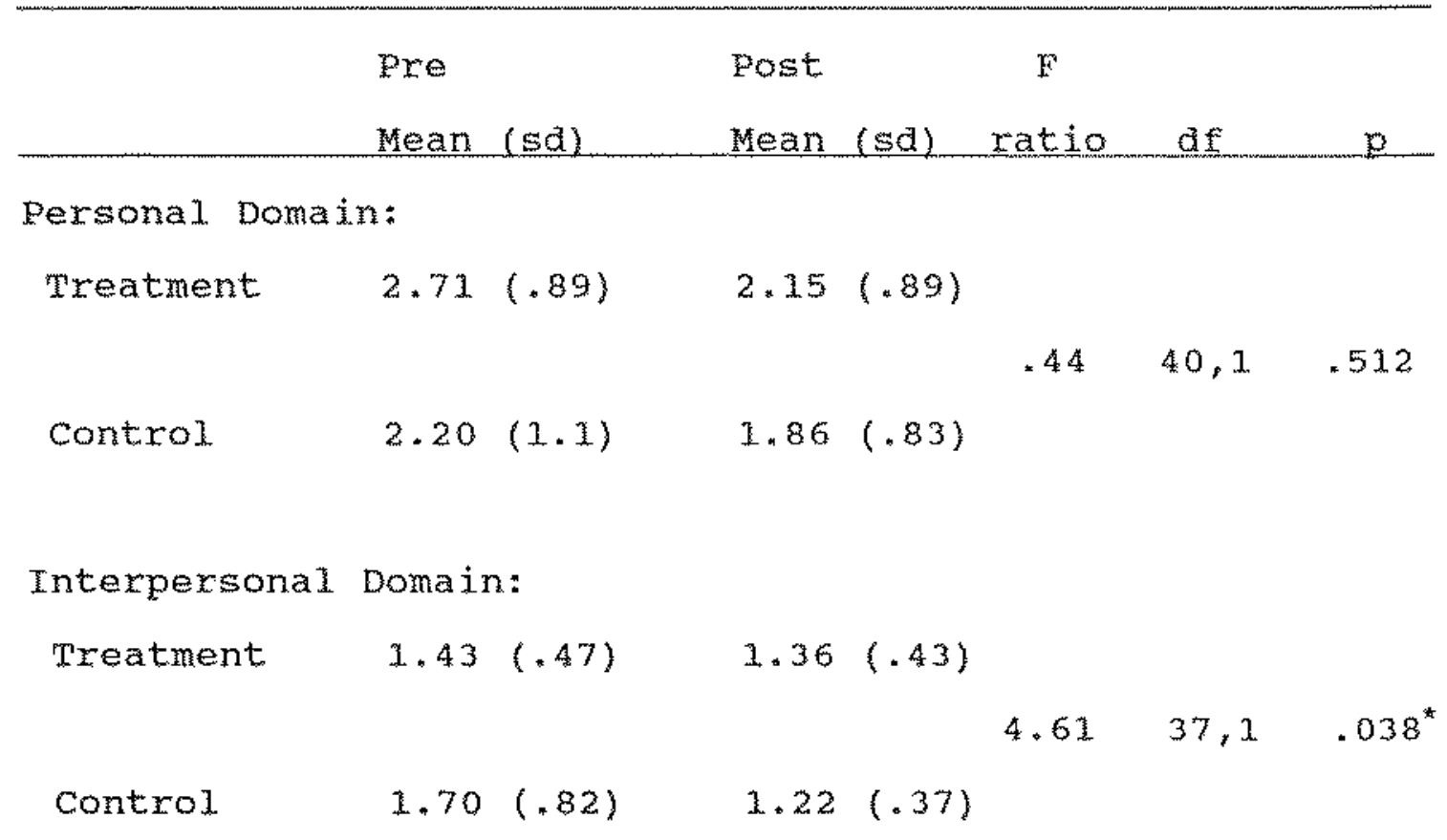

World view Domain:

$\begin{array}{llllll}\text { rreatment } & 1.65 & (.60) & 1.57 & (.56) & \\ & & & 1.76 & 37.3 & .193 \\ \text { Contxo1 } & 1.97 & (.69) & 1.62 & (.62) & \end{array}$

Overall Distress:

rreatment $\quad 1.90(.46) \quad 1.67(.50)$ $2.69 \quad 34,1 \quad .110$

control $2.00(.74) \quad 1.56(.47)$

5 Distress Ratings range from 1 to 5 on a wikert scale. 
Table 4

Means, standard Deviations, Alphas, and cormelations for Pre-test subscales on the CDP.

Standardized

Mean (sd) Alpha Item Alpha Corr. P

Critical

Thinking: $\quad 1.17(1.2) \quad .6329 \quad .6288$

$.1991 \quad .251$

critical

Discussion: $\quad 1.14(.85) \quad-.2259 \quad-.2293$ 
Table 5

Means, Standard Deviations, Alphas, and Correlations, for Post-test subscales on the cop.

\section{Standardized}

Mean (sd) Alpha Item Alpha Corr. p

Critical

Thinking: $\quad 1.17(1.5) \quad .8293 \quad .8336$

$.1771 \quad .309$

Critical
Discussion:
$1.06(.97)$
.1983
.1913 
Table 6

Means, Standara Deviations, Alphas and correlations for Pre-test Satisfaction Subscales on the TDS.

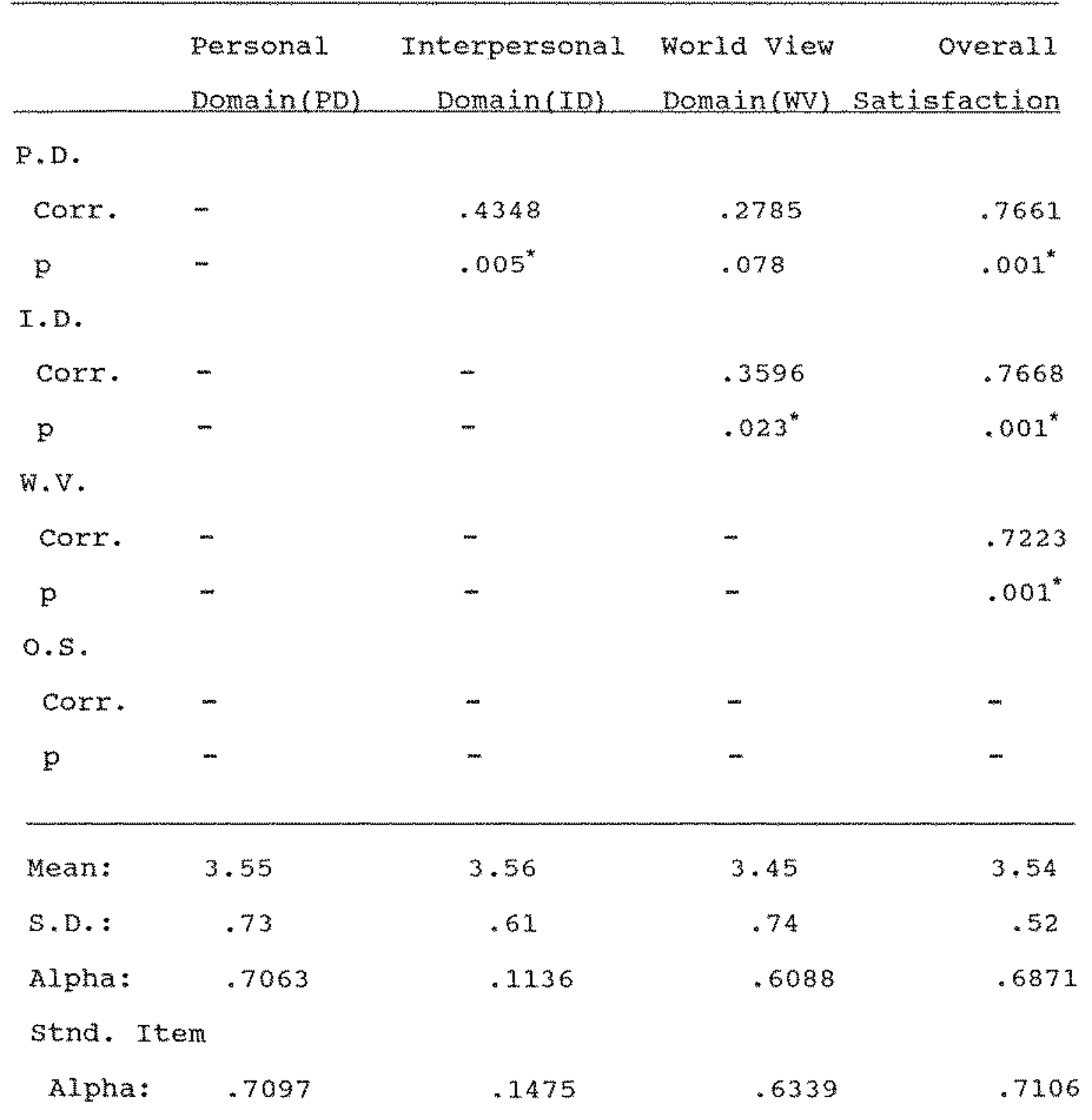


Table 7

Means, Standard Deviations, Alphas, and Correlations, for Pre-test Distress subscales on the IDS.

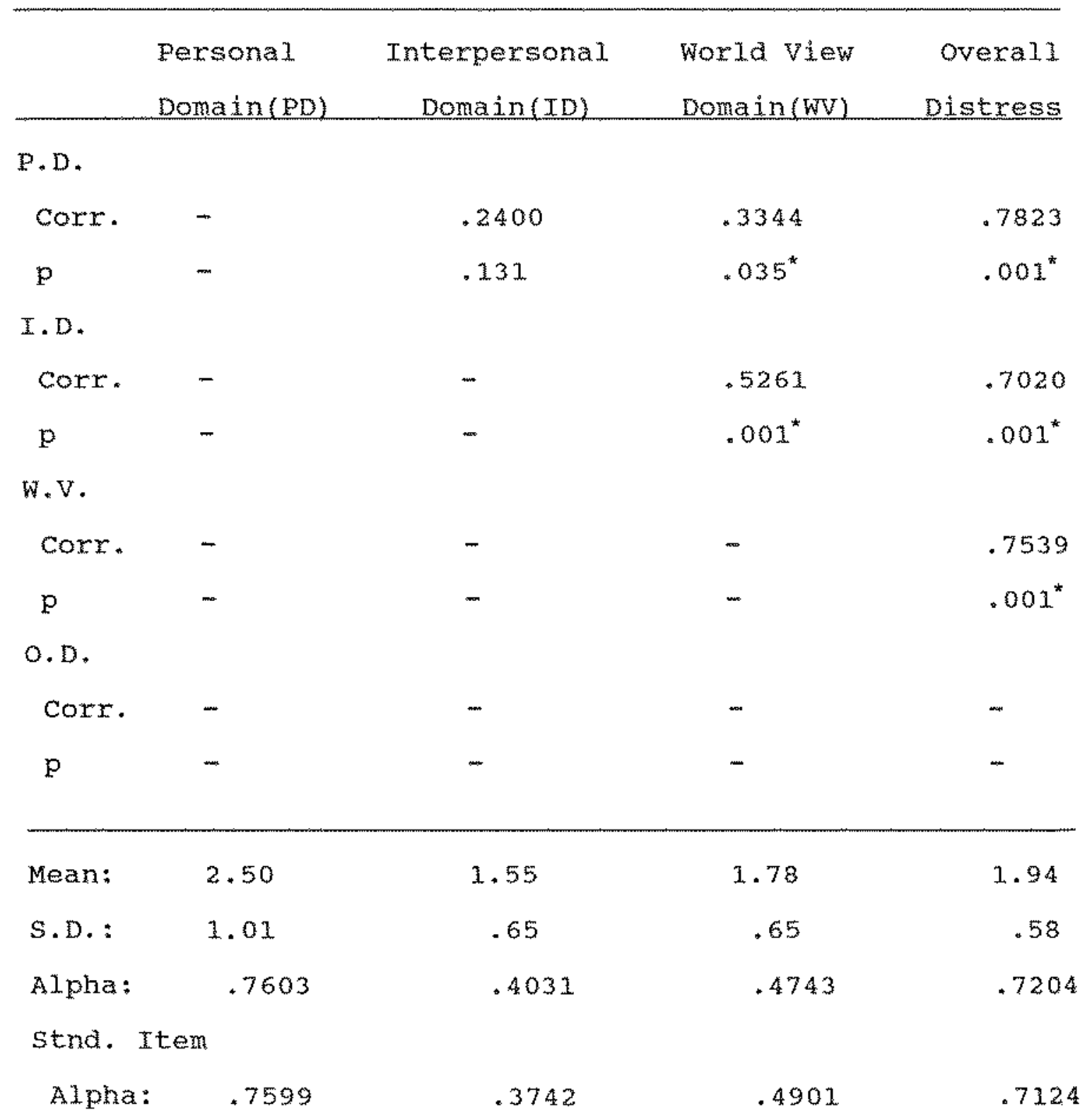


Table 8

Means, standard Deviations Aphas, and correlations for Post-test Satisfaction Subscales on the IDS.

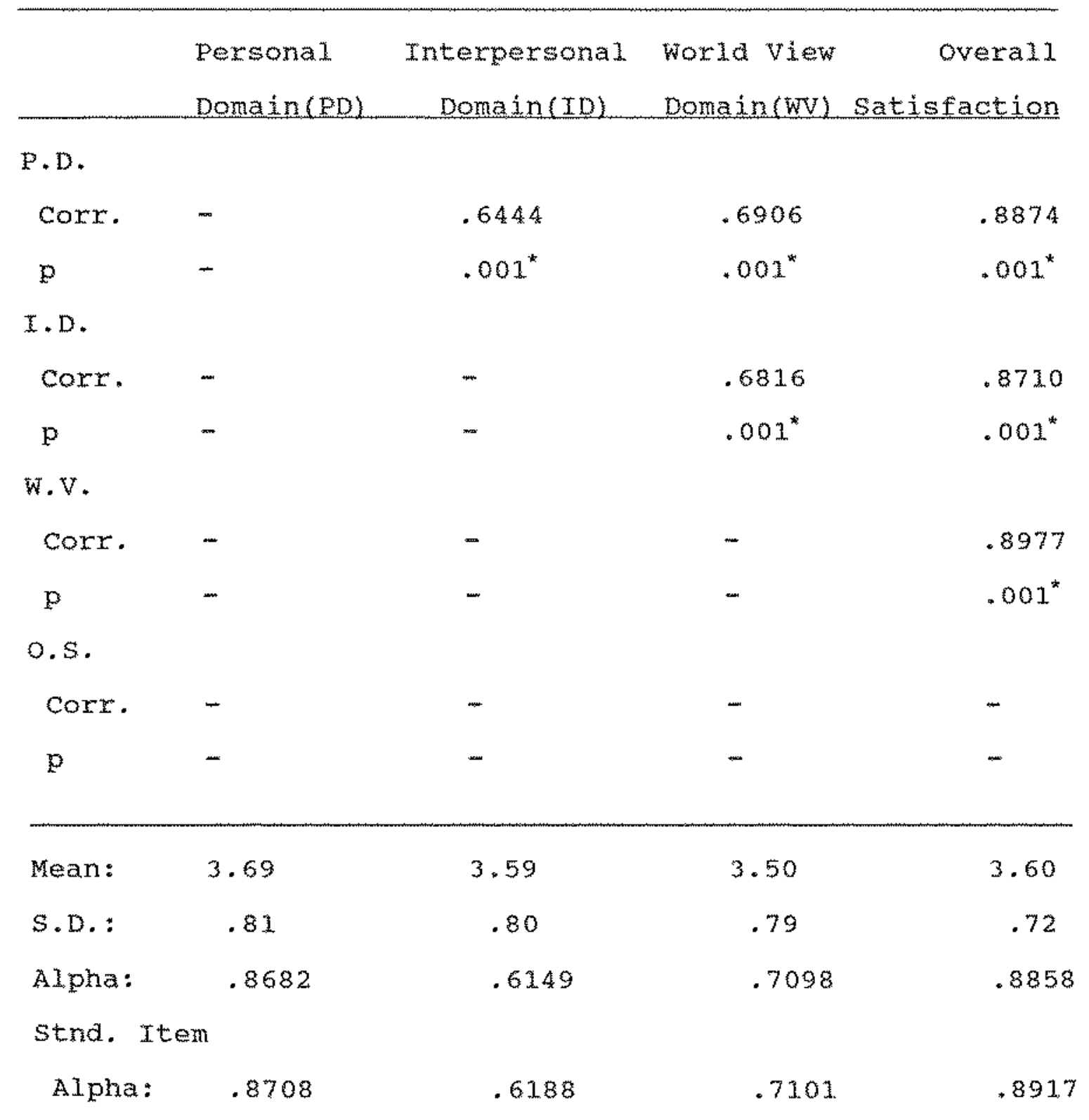


Table 9

Means, Standard Deviations, Alphas, and Correlations, cor Post-test Distress Subscales on the IDS.

\begin{tabular}{|c|c|c|c|c|}
\hline & $\begin{array}{l}\text { Pexsonal } \\
\text { Domatn }(\mathrm{PD})\end{array}$ & $\begin{array}{l}\text { Interpersonal } \\
\text { Domain(ID) }\end{array}$ & $\begin{array}{l}\text { Woxid view } \\
\text { Domain(WV) }\end{array}$ & $\begin{array}{l}\text { Overall } \\
\text { Distress }\end{array}$ \\
\hline \multicolumn{5}{|l|}{$P . D$} \\
\hline Corr. & - & .2851 & .5955 & .8874 \\
\hline$p$ & - & .075 & $.001^{\star}$ & $.001^{*}$ \\
\hline \multicolumn{5}{|l|}{$I \cdot D$} \\
\hline Corr. & - & - & .3284 & .5833 \\
\hline $\mathrm{p}$ & - & - & $.039^{*}$ & $.001^{*}$ \\
\hline \multicolumn{5}{|l|}{$\mathrm{W} . \mathrm{V} \cdot$} \\
\hline corr. & 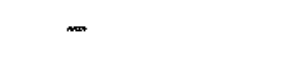 & $=$ & - & .8070 \\
\hline $\mathrm{p}$ & - & - & - & $.001^{*}$ \\
\hline \multicolumn{5}{|l|}{$0 . D$} \\
\hline Corr. & $m$ & $\cdots$ & $m$ & - \\
\hline $\mathrm{p}$ & - & - & $m$ & 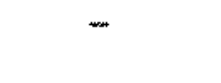 \\
\hline Mean: & 2.03 & 1.31 & 1.60 & 1.63 \\
\hline$S+D .:$ & .86 & .40 & $* 57$ & .48 \\
\hline Alpha: & .6903 & .3261 & .4479 & .7292 \\
\hline \multicolumn{5}{|c|}{ Stnd. Item } \\
\hline Alpha: & .6927 & .2730 & .4770 & .7063 \\
\hline
\end{tabular}


APPENDTX A 
Critical Decision Making and Problem Solving Scale Moral Dilemma

(CDP-MD)

Interview Protocol/Worksheet

-- Revised: $2 / 95$

Printed: $4 / 96$

CDI-MD.93 


\section{PART 1: Critical Thinking (Items I -IV)}

Getting the Interview Started -.. Have the subject begin by taking a few minutes to read the background information and first dilemma as indicated on the CDP-MDInterviewee's Copy.

Instructions to Participants (Read to subjects):

In Part 1 of this interview we are interested in how people think when they are making decisions and solving problems involving moral choices. We are going to be discussing some moral dilemmas. I am going to read them to you one at a time and then ask you questions about what you would do and why you would make that decision. If you need to spend more time with the readings you are welcome to look at each one privately after I read it aloud. Any questions? Let's begin. 


\section{Lying}

The adventures told here begin on a fine morning, early in the spring. Rob, the more enterprising of the three, had decided to try a hand at farming. Rob had purchased a few acres of farmland not far from where they lived and, since Hobbits are a close knit people, Sam and Dale volunteered to help get the farm started.

As they were walking along the road to the farm, Rob and Sam began talking about Sam's father. Sam had been on a trip to a far a way land that took several weeks. While he was away, his father had become seriously ill of an incurable disease and had died. Sam did not find out about his father"s death until he returned. Because Hobbits are very close, Rob had spent the last few days taking care of Sam's father. Sam's father had suffered a great deal during his last few days. Rob and Sam were talking about his father, and Sam asked Rob how his father's last days had been and if he had suffered much. Rob thought about what to tell Sam. On the one hand, he could tell Sam the truth, that his father had suffered a lot during his last days. Now, Rob knew that Sam felt very bad about his father's death and telling him that he had suffered wolld only make him feel worse. On the other hand, he could tell Sam that his father had not suffered very much. This would not be the truth, but Sam would probably not feel as bad if he did not think his father had suffered. Sam would never find out the truth if Rob did not tell him because there was no one else with his father during the last days. Rob was not sure about what to do so he considered his choices. On the one hand, he felt he had a duty or obligation to tell Sam the truth even though it would hurt him. On the other hand, he felt that by not telling him the truth he would spare him some pain.

If you were Rob, what would you do?

1) Tell the truth.

2) Don't tell the truth.

Why?

a) "In this study we are interested in finding out as much as we can about how people make choices. Therefore, we are especially interested in as much as you could tell us about how you made this choice"

b) "Are there any more details or information that you think might help us to understand how you made your choice?"

c) "Do you want to say more?" 


\section{Fair Day's Pay}

Rob, Sam and Dale continued on their journey and soon arrived at the farm. The farm was obviously going to need a lot of work. The three Hobbits set to work and the farm quickly began to take shape.

As the day drew to a close, work on the farm stopped. Hobbits, we noted earlier, delight in receiving as well as giving presents and Rob, grateful for the heip of Sam and Dale, decided to surprise them each with a nice present. Rob had five gold coins that he wanted to give them as presents for helping. A Hobbit gold coin is quite valuable. The trouble is that Rob could not decide how to share the coins. Both Hobbits had worked all day but Sam had worked harder than Dale. Rob felt he had an obligation to reward Sam more because he had worked harder than Dale. However, Rob also knew that Dale had been saving money for an operation that his mother needed to restore her eyesight, which was failing rapidly. Dale needed only three more gold coins. Rob was not sure about what to do so he considered his choices. On the one hand, he could give Dale three coins and Sam two, even though Sam had worked harder than Dale. That way Dale would have enough for his mother's operation. On the other hand, he could give Sam three coins and Dale two, even though Dale needed the extra coin for the operation. That way Sam would be rewarded for his extra work.

If you were Rob what do you think you would do?

1) Give three to Dale and two to Sam.

2) Give three to Sam and two to Dale.

Why?

a) "In this study we are interested in finding out as much as we can about how people make choices. Therefore, we are especially interested in as much as you could tell us about how you made this choice"

b) "Are there any more details or information that you think might help us to understand how you made your choice?"

c) "Do you want to say more?" 


\section{Breaking a Promise}

After Rob had given both Sam and Date their presents, the three Hobbits began to prepare dinner. And it was a splendid supper indeed, for all of the hard work and fresh air had given the Hobbits a hearty appetite. Later, while sitting on the porch, Sam told Rob that he had found a magic black mushroom in the field. Black mushrooms were said to have many different types of powers. It has been said that one bite of a black mushroom could make someone feel very happy. Black mushrooms, however, have also been said to make Hobbits act in strange ways, sometimes even causing them to harm themselves. Now, while Sam had a warm and friendly disposition, he was also noted for being very impulsive and for doing foolish things. Consequently, Sam asked Rob to keep the black mushroom for him. However, before giving Rob the mushroom, Sam made Rob swear a double solemn oath, which Hobbits take very seriously, to give him the black mushroom back whenever be asked for it.

Later on in the evening, in the middle of a fitful sleep, Sam woke up. He had been feeling very bad about his father, and he asked Rob to give him the black mushroom back because he wanted to eat some. Rob was not sure about what to do so he considered his choices. On the one hand, he felt that he had an obligation to give him the mushroom back because he had made a solemn promise to do so. On the other hand, he felt that if he did give it back Sam might do something to hurt himself.

If you were Rob, what would you do?

1) Give the mushroom back.

2) Keep the mushroom.

Why?

a) "In this study we are interested in finding out as much as we can about how people make choices. Therefore, we are especially interested in as much as you could tell us about how you made this choice"

b) "Are there any more details or information that you think might help us to understand how you made your choice?"

c) "Do you want to say more?" 


\section{You Broke It You Bought It}

Work on the farm continued. There was much to be done and the Hobbits worked with great enthusiasm. In fact, Dale and Sam even went so far as to go into town to borrow a plow from "The Merchant in order to speed up clearing the field.

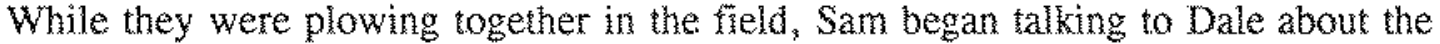
trip he had taken to a far away land, in spite of Dales protests that he should pay more attention to their task. Suddenly, the plow struck a huge boulder and the blade broke. The plow was runed. The Hobbits took it back to The Merchant and The Merchant asked Rob who was going to pay for the plow. Now, Hobbits do not have a formal court system in the same way that we "Big Folk" do. When a Hobbit violates one of "The Rules," as they refer to their laws, which have been handed down since ancient times, it falls upon the master of the house to serve as a combination policeman, judge, and warden. Because Dale and Sam live on Rob's farm The Merchant demanded that Rob insure that he receive nine gold coins for the broken plow.

After listening to The Merchant, Rob decided that his claim was justified and Sam and Dale would have to pay for the plow. One would have to pay five coins and the other would have to pay four, but he was not sure which one should pay more. To make matters worse, "The Rules" prevented Rob from getting personally involved with the settlement. Sam had told Rob that he could only afford to pay four coins for the plow because he needed to pay off the balance of the mortgage on the house he owns in town. He had been saving all year to pay it off. The balance due was one hundred gold coins and Sam only had one hundred and four coins. If he had to pay The Merchant more than four coins he would not have enough left for his mortgage, and since it was due next week he would lose his house. Rob was not sure what to do so he considered his choices. On the one hand, he felt he had an obligation to make Sam pay more than Dale because it was Sam's carelessness that caused the plow to break. On the other hand, if he made Dale pay the extra coin Sam would not lose his house.

If you were Rob what do you think you would do?

1) Have Dale pay more than Sam.

2) Have Sam pay more than Dale.

Why?

a) "In this study we are interested in finding out as much as we can about how people make choices. Therefore, we are especially interested in as much as you could tell us about how you made this choice"

b) "Are there any more details or information that you think might help us to understand how you made your choice?"

c) "Do you want to say more?" 


\section{PART 2: Critical Discussion (Items III-VI)}

Instructions to Participants (Read to subiects) :

In Part 2 of the interview we are interested in how people talk about issues when they try to come to an agreement on what is the right thing to do. Because we have to suppose that there is a disagreement to start with, I will be taking the opposite choice on the dilemmas from whatever you take. Please make the choice that you would normally choose or the one which you feel is right. I will take the other choice and we will talk abont the choices and try to come to some sort of an agreement about what to do. Any questions? We will begin by re-reading and discussing two of the previous dilemmas. 


\section{Breaking a Promise}

After Rob had given both Sam and Dale their presents, the three Hobbits began to prepare dinner. And it was a splendid supper indeed, for all of the hard work and fresh air had given the Hobbits a hearty appetite. Later, while sitting on the porch, Sam told Rob that he had found a magic black mushroom in the field. Black mushrooms were said to have many different types of powers. It has been said that one bite of a black mushroom could make someone feel very happy. Black mushrooms, however, have also been said to make Hobbits act in strange ways, sometimes even causing them to harm themselves. Now, while Sam had a warm and friendly disposition, he was also noted for being very impulsive and for doing foolish things. Consequently, Sam asked Rob to keep the black mushroom for him.

However, before giving Rob the mushroom, Sam made Rob swear a double solemn oath, which Hobbits take very seriously, to give him the black mushroom back whenever he asked for it.

Later on in the evening, in the middle of a fitful sleep, Sam woke up. He had been feeling very bad about his father, and he asked Rob to give him the black mushroom back because he wanted to eat some. Rob was not sure about what to do so he considered his choices. On the one hand, he felt that he had an obligation to give him the mushroom back because he had made a solemn promise to do so. On the other hand, he felt that if he did give it back Sam might do something to hurt himself.

If you were Rob what do you think you would do?

1) Give the mushroom back.

2) Keep the mushroom. 


\section{You Broke It You Bought It}

Work on the farm continued. There was much to be done and the Hobbits worked with great enthusiasm. In fact, Dale and Sam even went so far as to go into town to borrow a plow from The Merchant in order to speed up clearing the field. While they were plowing together in the field, Sam began talking to Dale about the trip he had taken to a far away land, in spite of Dale's protests that he should pay more attention to their task. Suddenly, the plow struck a huge boulder and the blade broke. The plow was ruined. The Hobbits took it back to The Merchant and The Merchant asked Rob who was going to pay for the plow. Now, Hobbits do not have a formal court system in the same way that we "Big Folk" do. When a Hobbit violates one of "The Rules," as they refer to their laws, which have been handed down since ancient times, it falls upon the master of the house to serve as a combination policenian, judge, and warden. Because Dale and Sam live on Rob's farm The Merchant demanded that Rob insure that he receive nine gold coins for the broken plow.

After listening to The Merchant, Rob decided that his claim was justified and Sam and Dale would have to pay for the plow. One would have to pay five coins and the other would have to pay four, but he was not sure which one should pay more. To make matters worse, "The Rules" prevented Rob from getting personally involved with the settlement. Sam had told Rob that he could only afford to pay four coins for the plow because he needed to pay off the balance of the mortgage on the house he owns in town. He had been saving all year to pay it off. The balance due was one hundred gold coins and Sam only had one hundred and four coins. If he had to pay The Merchant more than four coins he would not have enough left for his mortgage, and since it was due next week he would lose his house. Rob was not sure what to do so he considered his choices. On the one hand, he felt he had an obligation to make Sam pay more than Dale because it was Sam's carelessness that caused the plow to break. On the other hand, if he made Dale pay the extra coin Sam would not lose his house.

If you were Rob what do you think you would do?

1) Have Dale pay more than San.

2) Have Sam pay more than Dale. 


\section{Stealing}

After they had finished their affairs with The Merchant, the Hobbits had dinner and went to bed. They got up early the next morning and began working. While the Hobbits were working in the fleld, a friend of Rob's came by with news of his mother. Rob's mother had the same problem with her eyesight that Dale's had. Rob did not have the money for his mother's operation eiher, and he had far less than Dale. He needed one hundred gold coins. Rob's friend told him that his mother's eyesight was getting worse and that she might go blind. The only one who had that much money was Mr. Maggot, a miserly old Scrooge who lived on the next farm. Rob went over to ask him for the money, and Mr. Maggot turned him down. He said that he had worked and saved for a long time and that he wanted to keep his coins. Rob left Maggot's farm, but while he was leaving he saw that Mr. Maggot was going in to town for the afternoon. Rob had seen where $\mathrm{Mr}$. Maggot kept his gold coins and he knew that he could come back in the aftemoon and steal the 100 coins. Mr. Maggot had a whole room full of gold coins and would probably never even miss one hundred. Rob knew that there was no other way for him to get that many coins. He wasn't sure about what to do so he considered his choices. On the one hand, he felt he had an obligation to respect Mr. Maggot's right to keep the coins. On the other hand, he knew that if his mother did not have an operation she would probably lose her eyesight.

If you were Rob what do you think you would do?

1) Not take the coins.

2) Take the coins. 


\section{Punishment}

Suppose that before Rob could decide what to do, Sam, who knew about Rob's mother, had already taken the money, and that he had a friend help him. Together, they had taken 200 coins. When Mr. Maggot got back from town he discovered right away that the coins where missing (since it was his peculiar habit to count them three times a day) and went immediately to Rob's farm. At the farm he asked Rob to search the house and they found the 200 coins in Sam's room where he had hidden them. Confronted with the evidence, Sam confessed that he had indeed stolen them. Since Sam and his friend came under Rob's jurisdiction, Mr. Maggot demanded that Rob punish them for stealing the coins, because Hobbits consider stealing a very severe violation of "The Rules." Rob knew the standard punishment for an offense as severe as stealing was to serve time with one's head and hands locked in the pillories in the town square as a form of public humiliation. It was Rob's decision about how much time each Hobbit should spend in the pillories.

After confessing, Sam said that he took the coins to give his half to Rob for his mother"s operation. Sam"s friend, on the other hand, said that he took the coins so that he could use bis half to take a vacation trip that he had always wanted. Rob knew that stealing was a very serious offense and he thought about how he might punish Sam and his friend. On the one hand, he felt that he had an obligation to sentence them both to the same amount of time as punishment because they had both committed the same offense. On the other hand, he could sentence Sam to less time because he had taken the money in order to try and do some good.

If you were Rob what do you think you would do?

1) Punish Sam less than the friend.

2) Punish Sam and the friend equally. 
APPENDIX B 


\section{Identity Domain Scale}

Directions: We are interested in your thoughts and feelings about a variety of issues relating to your identity. Identity has to do with your sense of self. More specifically, we will be asking you about your satisfaction or dissatisfaction with the direction of your life. This survey has nine parts. Each part asks about a different content area related to your sense of self. You will be asked to describe what is good or positive and what is distressful or troublesome in each content area and how much you have thought about each of these areas. Please write your answers on both the bubble sheet and the description sheet provided. DO NOT WRITE ON THIS

QUESTIONAIRE. Please answer every question. 


\section{Diographical Data}

Please roord your answers on the infornation section of your bubble answer sheet.

Sex: Male Female

Grade: $7 \quad 8 \quad 9 \quad 10 \quad 11 \quad 12$

College: $\quad 13=$ Freshman

$14=$ Sophnore

$15 \ldots$ ynior

$16=$ Senior

Age: _._...___ (Indicate your age under "YR. ${ }^{*}$ on the answer sheet)

Race: (Undicate your race under " ${ }^{N}$ of special codes on the answer sheet)

$$
\begin{aligned}
& 1=\text { White } \\
& 2=\text { Black (Non-Wispanic) } \\
& 3=\text { Hispanic } \\
& 4=\text { Asiar } \\
& 5=\text { Native American } \\
& 6=\text { Other }
\end{aligned}
$$

Marital Status: (Indicate your marital status under "L" of special codes on the answer sheet)

$$
\begin{aligned}
& 1=\text { Single } \\
& 2=\text { Married } \\
& 3=\text { Divored } \\
& 4=\text { Widowed }
\end{aligned}
$$




\section{Domain I:}

\section{Personal Development}




\section{Part A asks about career goals.}

\section{PART A: SECTION I}

We would like you to identify and describe what, if anything, you consider good or positive about your thoughis, feelings, practices, experiences, or any other issues that are important to you about your career goals. Below is a list of content features with examples. Look them over carefully and identify the most important area of positive experiences for you. Enter the cole letter on the bubble sheet and describe this area of importance in your own words on the description sheet provided.

\section{Positive Content Features \\ (with examples)}

Code (A) DECISlON: The achal decision itself and/ot the process of making a decision.

EX: $\quad 1$ know what $I$ want to pursue

- t wan to be a techer

Code (B) ACHEVEMENT: The achievement of your aspirations of goals.

I believe I can accomplish my goals

I am currently in a job that will help me in the future

Code (C) REWARDS: The rewards related to your decision

I will be challenged and safisfied

$-I$ will be able to help children

Code (D) NO ISSUES: This is not an important issue for you

1. Go to your description sheet and recond your cole letter and your description of the innortant issues.

2. How positive is this issue to you at this moment?

$\begin{array}{ccccc}\text { Not } & \text { A little } & & \text { Very } & \text { Extremety } \\ \text { Positive } & \text { Positive } & \text { Positive } & \text { Positive } & \text { Positive } \\ \text { A } & \text { B } & \text { C } & \text { D } & \text { E }\end{array}$

3. In general, how positive is this issue in your life?

$\begin{array}{lcccc}\text { Not } & \text { A little } & & \text { Very } & \text { Extremely } \\ \text { Positive } & \text { Positive } & \text { Positive } & \text { Positive } & \text { Positive } \\ \text { A } & \text { B } & C & \text { D } & \text { E }\end{array}$




\section{PART A: SECTON II \\ Distrexsful Content Features \\ (with examples)}

We would like you to identify and describe what, if anything, you consider distressful and troublesome about your thoughts, feelings, practices, experiences, or any other issues that are important to you abolts your career goals. Below is a list of content features with examples. Look them over carefully and identify the most important area of distressful experiences for you. Enter the code letter on the bubble sheet and describe this arta of importance in your own words on the description shet provided.

Code (A) DECISION: The actual decision itself and/or the process of making a decision.

I don't know whal 1 want to purside?

-1 an confused about my fature

Code (B) ACHIEVEMENT: The achievement of your aspirations or goals.

I may not have the grades to get into graduate school to become a teacher

I may not be able to get the experience that will help me in the futura

Code (C) REWARDS: The rewards related to your decision

- I may not be challenged and satisfied

-1 may not be able to have the financial adwancement 1 want

Code (D) NO ISSUES:This is not an important issue for you

4. Go to your description sheet and record your cole letter and your description of the important issues.

5. How distressful is this issue to you at this moment?

$\begin{array}{ccccc}\text { Not } & \text { A bitte } & & \text { Very } & \text { Extremely } \\ \text { Distressful } & \text { Distressfut } & \text { Distressful } & \text { Distressful } & \text { Distressful } \\ \text { A } & \text { B } & \text { C } & \text { D } & \text { E }\end{array}$

6. In general, how distressful is this issue in your life?

$\begin{array}{llccc}\text { Not } & \text { A little } & & \text { Very } & \text { Extremely } \\ \text { Distressful } & \text { Distressful } & \text { Distressful } & \text { Distressful } & \text { Distressful } \\ \text { A } & \text { B } & \text { C } & \text { D } & \text { E }\end{array}$

7. Have you had distress about this issue for longer than three months?
(A) Yes
(B) No

8. Have you had distress about this issue which significantly interfered with your daily itiving?
(A) Yes
(B) No

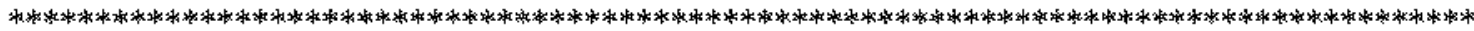

9. Of the following statements, which best describes your current thoughts and feelings with respect to your career goals:

(A). I am not sure about my career goals and I haven't spent much time questioning or thinking about it.

(B). After a lot of self-examination and experience, I bave established a cleat sense of ny career goals.

(C). I have never really questioned my career goals because I have always known what I wanted to do.

(D). After a lot of self-exanination and experience, I have Nor established a clear sense of

my career goals. 


\title{
Pare $\mathrm{B}$ asks about your sense of self
}

\author{
PART B: SECTION \\ Positive Content Features \\ (with examples)
}

We would like you to identify and describe what, if anything, you consider good or positive about your thoughts, feelings, pactices, experiences, or any other issues that are important to you about your sense of self. Below is a list of content feamures with examples. Look them over carefully and identify the most important area of positive cxperiences for you. Enter the code letter on the bubble sheet and describe this area of importance in your own words on the description sheet provided.

Code (A) SELF ESTEEM: The teelings you have about yourself and who you are.

-I feet good about myself

$-I$ am $a$ confident person

Code (B) BODY IMAGE: The thoughts and feelings you have about the way you perceive your physical apperatance.

I think I am very attractive and I like the way I look

I am physically fit which makes me feel good thouk how I look

Code (C) SELF TMAGE: The thoughts and feelings that reflet your personal qualities.

-I am a positive person and I know what I wan in life

I am a caing and loving person

Code (D) NO ISSUES: This is not an important issue for you

10. Go to your description shest and recort your code letter and your aescription of the important issues.

11. How positive is this issue to you at this moment?

$\begin{array}{ccccc}\text { Not } & \text { A little } & & \text { Very } & \text { Extrenely } \\ \text { Positive } & \text { Positive } & \text { Positive } & \text { Positive } & \text { Positive } \\ \text { A } & \text { B } & \text { C } & \text { D } & \text { E }\end{array}$

12. In general, how positive is this issue in your life?

\begin{tabular}{|c|c|}
\hline $\begin{array}{l}\text { Not } \\
\text { Positive }\end{array}$ & $\begin{array}{l}\text { A little } \\
\text { Positive }\end{array}$ \\
\hline
\end{tabular}
A
B
$\mathrm{C}$
$\mathrm{D}$
$\mathrm{E}$ 


\section{PART B: SECTION II}

\section{Distressful Content Festures \\ (with examples)}

We would like you to identify and describe what, if anything, you consider distressful or troublesone about your thoughts, feelings, practices, experiences, or any other issues that are important to you about your sense of self. Below is a list of content features with examples. Look them over carefuly and identify the most important area of alstressful expertences for you. Enter the code letter on the bubble shet and describe this area of importance in your own words on the description sheet provided.

Code (A) SELF ESTEEM: The feelings you have about yourself and who you are

I sometimes feel inadequate

-I feel that $I$ may not be strong enough to acheive my goats

Code (B) BODY MACE: The thoughts and feelings you have about the way you perceive your physical appeanance.

I don't like my body

I am overweight for the way I would like to look

Code (C) SELF IMAGE: The thoughts and feelings that reflect your personal qualities.

I am easlity intiminated and pushed to do things I don't agree with

-1 am pesimistic and I usually see the bad side of situations

Code (D) NO ISSUES: This is not an important issue for you

13. Go to your description sheet and record your code letter and your description of the important issues.

14. How distressful is this issue to you at this moment?

$\begin{array}{clccc}\text { Not } & \text { A little } & & \text { Very } & \text { Extremaly } \\ \text { Distressful } & \text { Distressful } & \text { Distressful } & \text { Distressful } & \text { Distressful } \\ \text { A } & \text { B } & C & \text { D } & \text { E }\end{array}$

15. In genfal, how distressful is this issue in your life?

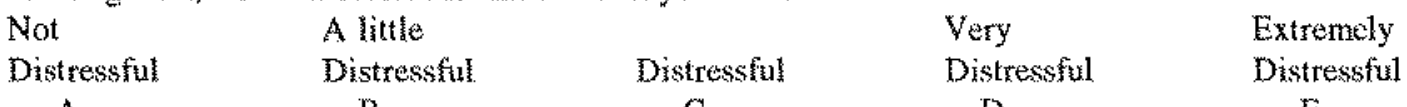

A

$\mathrm{B}$

C.

$\mathrm{D}$

$\mathrm{E}$

16. Have you had distress about this issue for longer than three months?
(A) Yes
(B) No

17. Have you had distress about this issue which significantly interfered with your daily living?
(A) Yes
(B) No

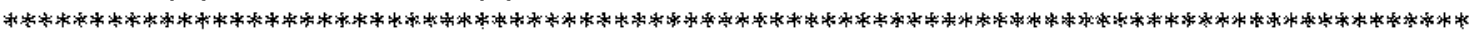

18. Of the following statements, which best describes your current thoughts and ceelings with respect to your sense of self:

(A). After a lot of self-examination and experience, I have NOT established a clear sense of self.

(B). After a lot of selfexamination and experience, I have established a clear sense of self.

(C). I have never really questioned my sense of self because I have always known who I am.

(D). I am not sure about how I fuel about my sense of self and I haven't spent much time questioning or thinking about it. 


\title{
Part $C$ asks abont long-term life goals.
}

\author{
PART C: SECTION 1 \\ Positive Content Fuatures \\ (wirk exampley)
}

We would hike you to dentify and describe what, if anything, you consider good or positive about your thoughts, feelings, practices, experiences, or any other issues that are important to you about you long-tem life goals. Below is a list of content fertures with examples. Look them. over carefully and identify the most important area of positive experiences for you. Enter the code letter on the bubble shet ard describe this area of importance in your own words on the description sheet provided.

Code (A) DECISION: The actual decision itself and/or the process of making it.

1 feel thave made a positive decision

-Someday 1 mould like to be a good wife and mother

Code (B) ACHIEVENENT: The achieventent of your aspirations or goals.

- I think 1 have the personal qualities to achieve my goals

-I am trying to be a well-rounded indiviatual

Code (C) REWARDS: The rewards retated to ycur decision -1 want to make a difference in the world

-I want to have independence and security

Code (D) NO ISSUES: This is not an issue for you

19. Go to your description sheet and tecord your code letter and your description of the imporant issues.

20. How positive is this issue to you at this moment?

\begin{tabular}{|c|c|c|}
\hline Not & A Intue & \\
\hline Positive & Positive & Positive \\
\hline
\end{tabular}
A.
$\mathrm{B}$
$\mathrm{C}$
D
E

21. In general, how positive is this issue in your life?

$\begin{array}{lcccc}\text { Not } & \text { A little } & & \text { Very } & \text { Extremely } \\ \text { Positive } & \text { Positive } & \text { Positive } & \text { Positive } & \text { Positive } \\ \text { A } & \text { B } & \text { C } & \text { D } & \text { E }\end{array}$




\section{PART C: SECTEON \\ Distrexsful Content Fatures \\ (with exampless)}

We would like you to identify and describe what, if anything, you consider distrestuful or troublesome about your thoughts, feelings, practices, experiences, or any other issues that are important to you about your long tem life goals. Below is a list of content features with examples. Look them over carefully and identify the most important area of distressful experiences for you. Enter the conte letter on the bubble sheet and describe this area of importance in your own words on the description sheet provided.

Code (A) DECISION: The actual decision itself and/or the process of making it

-I have not decided what to do with my life

-I am not sure if my choice is the right thing for me

Code (B) ACHIEVEMENT: The achievement of your aspirations or goals.

I feel I won't be able to achieve my goals

I worry that I may never get married.

Code (C) REWARDS: The rewards related to your decision

-1 may not be challenged and satisfied.

-My children may become rebellious

Code (D) NO ISSUES: This is not an issue for you

22. Go to your description sheet and record your code letter and your description of the impotant issues.

23. How distressful is this issue to you at this moment?

$\begin{array}{llccc}\text { Not } & \text { A fitte } & & \text { Very } & \text { Extremely } \\ \text { Distressful } & \text { Distressul } & \text { Distressful } & \text { Distressful } & \text { Distressful } \\ \text { A } & \text { B } & \text { C } & \text { D } & \text { E }\end{array}$

24. In general, how distressful is this issue in your life?

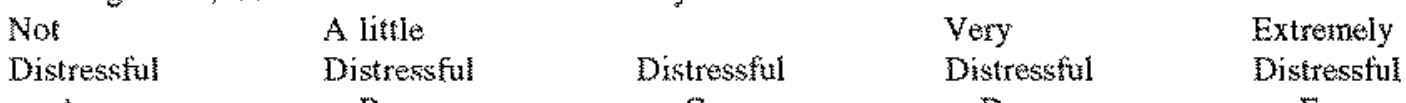

A

B

C

$\mathrm{D}$

$\mathrm{E}$

25. Have you had distress abont this issue for longer than three months?
(A) Yes
(B) $\mathrm{No}$

26. Have you had distress ghout this issue which signifeantly interfered with your daily living?
(A) Yes
(B) No

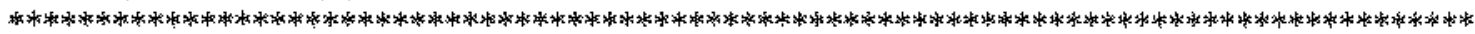

27. Of the following statements, which best describes your current thoughts and feelings with respect to your long-term life goals:

(A). I am not sure about my long-tern life goass and I haven't spent much time questioning or thinking about it.

(B). After a lot of self-examination and experience, I have Not established a clear sense of my long-term life goals.

(C). I have never really questioned my long-term life goals because I have always known what I wanted out of life.

(D). After a lot of self-exatuination and experience, I have established a clear sense of ny longterm life goals. 


\section{Domain II:}

\section{Interpersonal Development}




\section{Part D asks about friendships.}

\section{PART D: SECTION \\ Positive Content Features \\ (with examples)}

We would like you to identify and describe what, if anything, you consider good or positive about your thoughts, feelings, practices, experiences, or stay other issues that are important to you about your friendskips. Below is a list of content features with examples. Look then over carefully and identify the most important areat of positive experiences for you. Enter the code letter on the bubble sheet and describe this area of mimportance in your own words on the description sheet provided.

Code (A) PERSON QUALITIES: The qualities of the persons involved in the friendship - My friends whierstatd the

My friends are loyal

Code (B) FRIENDSHP OUALITIES: The qualities of the friendshyp itself

- We both know we can count on each other

-My friends and Thave mutual respect and honesty

Code (C) RELATIONSIUP PROCESSES: The process \& interactions telated to the friendships. -My friend gites me good advice when I need it most

-1 enjoy shoring my feelings and experiences

Code (D) NO ISSUES: This is not an issue for you

28. Go to your description sheet and record your code letter and your description of the important issues.

29. How positive is this issue to you at this moment?

$\begin{array}{lcccc}\text { Not } & \text { A little } & & \text { Very } & \text { Extremely } \\ \text { Positive } & \text { Positive } & \text { Positive } & \text { Positive } & \text { Positive } \\ \text { A } & \text { B } & \text { C } & \text { D } & \text { E }\end{array}$

30. In general, how positive is this issue in your life'?

\begin{tabular}{|c|c|c|c|c|}
\hline Not & A little & & Very & Extrenaly \\
\hline Positive & Positive & Posifive & Positive & \\
\hline
\end{tabular}
A
B
$\mathrm{C}$
D
$\mathrm{E}$ 


\section{PART D: SECTION 1 \\ Distressful Content Features \\ (uith examples)}

We would like you to identify and describe what, if anything, you consider bistresstul or troublesome about your thoughts, feelings, practices, experiences, of any other iskiles that are important to you about your friendships. Below is a list of content features with examples. Look them over carefully and identify the nost important area of distressfut experiences for you. Enter the code letter on the bubble sbeet and describe this area of importance in your own words on the description sheet provided.

Code (A) PERSON QUALTIES: The qualities of the persons involved in the friendship -My friend can be secresive sometimes

-My friends talk bethind my back

Code (B) FREENDSHIP QUALITIES: "The qualities of the frienşship itself -My friends and I have not been able to accept each other's faults

-It can be difficult to have friendships with people of the opposite sex

Code (C) RELATIONSHIP PROCESS: The process \& interactions related to the fricndships.

-It is nof fair that one of us is giving more than the other

-Sometimes lying interferes with the ability for friends to share intimate secrets

Code (D) NO ISSUES: This is not an issue for you

31. Go to your description sheet and tecord your code leter and your description of the important issues.

32. How distressful is this issue to you at this moment?

\begin{tabular}{|c|c|}
\hline Not & A lintle \\
\hline Distressfill & Distressful \\
\hline
\end{tabular}
A
B
C
D
E

33. In general, how distressful is this issue in yout life?

$\begin{array}{lllll}\text { Not } & \text { A little } & & \text { Very } & \text { Extremely } \\ \text { Distressful } & \text { Distresfful } & \text { Distressful } & \text { Distressful } & \text { Distressful }\end{array}$
A
B
$c$
D
E

34. Have you had distress about this issue for longer than three months?
(A) Yes
(B) No

35. Have you had distress about this issue which significanty interfered with your daily living?
(A) Yes
(B) No

36. Of the following statements, which best describes your current thoughts and ceelings with resnet to your friendships:

(A). I am still exploring what types of friends are right for toe at this point in my life.

(B). After a lot of self-examination and experience, I have established a clear sense of what typo of friendships I want and I choose my friends accordingly.

(C). I am not really sure about what I want in a friend and I have not given it much fhought.

(D). I know what 1 want in a friend and 1 have never really had to guestion it. 


\section{Part E asks about belonging to groups. \\ PART E: SECTION}

\section{Posîtive Content Features \\ (with exampless)}

We would like you to identify and describe what, if anything, you consider goou or positive about your thoughts, feelings, practices, experiences, or any other issues that are important to you about your group involventent. Below is a list of content features with examples. Look them over carefully and identify the nost important area of positive experiences for you. Enter the cole letter on the bubble sheet and atescribe this area of importance in your own words on the description sheet provided.

Code (A) GROUP QUALTUES: The qualities of the group.

The group 1 belong to is very supportive.

-The group 1 belong to gives me a sense of belonging

Code (B) LNDIVIDUAL OUALITIES: The quatities of the persons involved in the group.

-I feel I can contribute to the goals of my group

-The people in my group and myself have similar interests

Cade (C) GROUP PROCESS: Processes or interactions of belonging/not belonging to a gromp. - Provides soctal interaation which fosters communication

We work well together as a team and have a lot of cooperation

Code (D) NO ISSUES: This is not an issue for you

37. Go to your description sheet and record your cole letter and your description of the important issues.

38. How positive is this issue to you at this moment?

Not

Positive

A
A little

Positive

B
Positive

c
Very

Positive

D
Extrenely

Positive

E

39. In general, how positive is this issue in your life?

Not

A little

Positive

A
Posilive

B
Positive

$\mathrm{C}$
Very

Positive

D
Extremely

Positive

E 


\section{PART E: SECTION Il \\ Distressful Content peatures \\ (with examples)}

We would like you to identify and describe what, if anything, you consider distressful or troublesome about your thoughts, feetings, practices, experiences, or any other issues that are important to you about your group involvement. Below is a list of content features with examples. Look them. over carefully and identify the most important area of distressful experiences for you. Enter the cede letter on the bubble sheet and describe this area of importance in your own words on the description sheet provided.

Code (A) GROUP QUALITEES: The qualities of the group.

- Sometimes my group is too militant

+Sometimes I disagree with the group's goals

Code (B) INDIVIDUAL QUALITIES: The qualities of the persons involved in the group.

-Certain people in the group do not represent the group's ideals

-Some people in the group sit back and let others do all the work

Code (C) GROUP PROCESS: Processes or interactions of betonging/not belonging to a group.

-5 Sometimes I feel irolated and alone even though 1 am a member of the group

- I feel not everone has a voice in the group

Code (D) NO ISSUES: This is not an issue for you

40. Go to your description sheet and record your code letter and your description of the important issues.

41. How distressful is this issue to you at this moment?

$\begin{array}{ccccc}\text { Not } & \text { A little } & & \text { Very } & \text { Extemely } \\ \text { Distressul } & \text { Distressiul } & \text { Distressful } & \text { Distressful } & \text { Distressful } \\ \text { A } & \text { B } & \text { C } & \text { D } & \text { E }\end{array}$

42. In general, how distressful is this issue in your life?

$\begin{array}{llccc}\text { Not } & \text { A little } & & \text { Very } & \text { Extremely } \\ \text { Distressful } & \text { Distressful } & \text { Distressful } & \text { Distressul } & \text { Distressful } \\ \text { A } & \text { B } & \text { C } & \text { D } & \text { E }\end{array}$

43. Have you had distress about this issue for longer than three months?
(A) Yes
(B) No

44. Huve you had distress about this issue which significantly interfered with your daty lining?
(A) Yes
(B) No

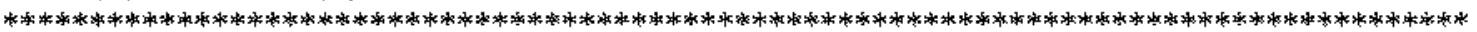

45. Of the following statements, which hest describes your current thoughts and feelings with respect to belonging to groups:

(A). I haven't spent much time questioning or thinking about what type of groups li should

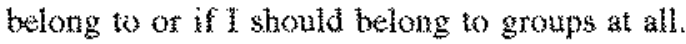

(B). I know what type of group involvement is best for me and I have never really had to question it.

(C). After a lot of selfexamination and experience. I still have NoT established a clear sense of the type and level of group involvement would be best for me.

(D). After a lot of selfexatuination and experience, I have extablished a clear sense of the vype and level of group involvernent would be best for me. 


\section{Dart $\mathrm{F}$ asks about gender and sexuality issues. \\ PART F: SECTION}

\section{Pesîtive Content Features}

We would like you to identify and describe what, if anything, you consider good or positive about your thoughts, feelings, practices, experiences, or any other issues that are important to you about your gender and sexulify. Below is a list of content features with examples. Look then over carefully and identify the most important area of positive experiences for yot. Enter the code letter on the hubble sheet and describe this area of importance in your own words on the description sheet provided.

(with examples)

Code (A) GENDER: The role and function that you play in society due to your gender.

-I feet positive that $I$ am able to carry a child

-I benefit from the statis that society assigns me

Code (B) SEXUALTY: The role that sexualizy play in your life.

-I understand my sexuatity and 1 an comfortable with myself

- Accepting my sexuality preference has given me a sense of power in my life

Code (C) SEX: The role that sex plays in your tife

-I feel posinive about my decision to become sexually active

I have had very positive sexual experiences

Code (D) NO ISSUES: This is not an issue for you

46. Go to your description sheet and record yout code lefter and your description of the important issues.

47. How positive is this issue to you at this moment?

Not

Positive

A
A little

Positive

B
Very

Positive

D
Extremely

Positive

E

48. In general, how positive is this issue in your life?

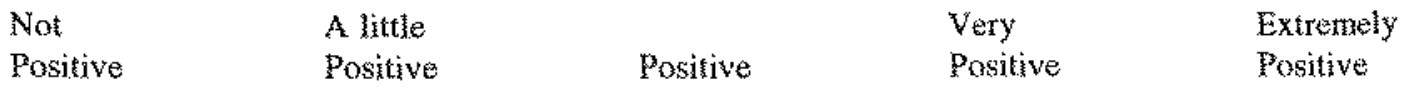

A

B
$\mathrm{C}$
D

E 


\section{PART SECTION II \\ Distresiful Content Features \\ (with examples)}

We would like you to identify and describe what, if anything, you consider distressful or troublesome about your thoughts, feelings, practices, experiences, or any ofher issues that are important to you about your sexulaity and gender. Below is a list of content features with examples. Look them over carefully and identify the most important area of distressful experiences for you. Enter the code letter on the bubble sheet and describe this area of importance in your own words on the description sheet provided.

Code (A) GENDER: The role and function that you play in society aue so your gender.

-I hate the physical linitations associated with my gender

Because of my gander, $l$ am often a victim of discrimination and sexual harassment

Code (B) SEXUALITY: The role that sexulatity play in your fife.

I am worried about the social implications of being a homosexial

- I am not sure about my sexual preference

Code (C) SEX: The role that sex plays in your life

-I feal $I$ an too occupied by sexual thoughts

-I'm not sure I want wo become sexually acive

Code (D) NO ISSUES: This is not an issue for you

49. Go to your description sheet and record your code leter and your description of the important issues.

50. How distressful is this issue to you at this moment?

$\begin{array}{clccc}\text { Not } & \text { A little } & & \text { Very } & \text { Extremely } \\ \text { Distressful } & \text { Distressful } & \text { Distressful } & \text { Distressful } & \text { Distressful } \\ \text { A } & \text { B } & \text { C } & \text { D } & \text { E }\end{array}$

51. In general, how distressful is this issue in your life?

$\begin{array}{clccc}\text { Not } & \text { A little } & & \text { Very } & \text { Extremely } \\ \text { Distressful } & \text { Disiressful } & \text { Distressful } & \text { Distressful } & \text { Distressful } \\ \text { A } & \text { B } & \text { C } & \text { D } & \text { E }\end{array}$

52. Have you had distress about this issue for longer than three months?
(A) Yes
(B) $\mathrm{No}$

53. Have you had distress about this sssue which significantly interfered with your daily living?
(A) Yes
(B) No

54. Of the following statements, which best describes your current thoughis and feelings with respect to gender and sexuality issues:

(A). I have thought about the many issues I must deal with in relation to my gerverer and my sexuality, but $l$ have not yet defined the role $/$ will take.

(B). I am not sure about my gender role or sexuality and I have not spent much time questioning or thinking about if.

(C), I have never really questioned my gender rote or my sexuality because l have used my purents as role nodels.

(D). I have thought a lot about different gender roles or my sexuality and I have chosen the one that is best for me. 


\section{Domain III:}

\section{Beliefs About the World}




\section{Part $\mathrm{C}$ asks about religious issues. \\ PART G: SECTION I \\ Positive Cortent features \\ (with examples)}

We would like you to identify and describe what, if anything, you consider good or positive about your thoughts, feelings, practices, experiences, or any other issues that are important to you about your religion. Below is a list of content features with examples. Look then over carefully and identify the most important area of positive experiences for you. Enter the code letter on the bubble sheet and describe this area of importance in your own worts on the description sheet provided.

Code (A) BELIEFS: The inffuence of your refigious beliefs on your life

- I believe in God

-Due to my choice, I don't have to depend on religion or God for strength

Code (B) MEANINOIDIRECTION: The implications that your befiefs on the quality of your life.

-My retigion teaches me how to live my daily life

-My religion gives me a perspective for what is imponant in life

Code (C) RULES AND PRACTICES: Inplications that your beliefs have on governing your life.

I enjoy going to my place of worship

-I feel free from restrictions taid down by religions

Code (D) NO ISSUES: This is not an issue for you

55. Go to your description sheet and record your code letter and your description of the important issues.

56. How positive is this issue to you at this monent?

\begin{tabular}{|c|c|c|c|}
\hline & A little & & $\begin{array}{l}\text { Very } \\
\text { pecitiy }\end{array}$ \\
\hline Positive & Positive & Positive & Positive \\
\hline
\end{tabular}
A
$\mathrm{B}$
$\mathrm{C}$
D
E

57. In general, how positive is this issue in your life?

\begin{tabular}{|c|c|}
\hline Not & A little \\
\hline Positive & Positive \\
\hline
\end{tabular}

A

B $\quad$ C

$\mathrm{D}$

E 


\section{PART G: SECTION II \\ Distressful Conten Teatures \\ (with examples)}

We would like you to identify and describe what, if anything, you consider distsesstul or troublesome about your thoughts, feelings, practices, experiences, or any other issues that are amportant to you about your religion. Below is a list of content fextures with examples. Look them over carefully and identify the most important area of distressful experiences for you. Enter the cole letter on the bubble sheet and describe this area of importance in your own words on the description sheet provided.

Code (A) BELIEFS: The influence of yout religious beliefs on your life

-My religious beliefs make me feel guilty

I ofien feel judged by my lack of beliefs

Code (B) MEANING/DIRECTION: The implications that your heliefs on the qualty of your life.

- It is difficult to live up to the expenations laid down by my religion

-My parent's religion meaks nothing to me.

Code (C) RULES AND PRACTICES: Implications that your beliefs have on governiag your life -I think that certain religious restrictions are silly

It is difficult to follow certain religious rules and pratices

Code (D) NO ISSUES: This is not an issue for you

58. Go to your description sheet and record your code letter and your description of the imortant issues.

59. How distressful is this issue to you at this monent?

$\begin{array}{llccc}\text { Not } & \text { A listle } & \text { Very } & \text { Extremely } \\ \text { Distressful } & \text { Distressful } & \text { Distressful } & \text { Distressful } & \text { Distressful } \\ \text { A } & \text { B } & \text { C } & \text { D } & \text { E }\end{array}$

60. In general, how distressfit is this issue in your life?

$\begin{array}{llccc}\text { Not } & \text { A little } & & \text { Very } & \text { Extremely } \\ \text { Distressful } & \text { Distressful } & \text { Distressful } & \text { Distressful } & \text { Distressful } \\ \text { A } & \text { B } & \text { C } & \text { D } & \text { E }\end{array}$

61. Have you had distress about this issue for longer than three months?
(A) Yes
(B) $\mathrm{No}$

62. Have you had distress about this issue which significantly interfered with yout daily living?
(A) Yes
(B) $\mathrm{No}$

63. Of the following statements, which best describes your current thoughts and feelings with respect to religious issues:

(A). I am looking at different religious issues in terms of what is right for me, but I am still not sure what religion means to me.

(B). I have never really questioned my religious beliefs because I have always known what I believed.

(C). I am not sure about ny religious beliefs and I have not spent much time questioning or thinking about it.

(D). I have thought a lot about rejigious matters and I have chosen the path that is right for me 


\section{Part $\mathrm{I}$ asks about moral issues. \\ PART H. SECTION}

\section{Positive Content Teatures \\ (with examples)}

We would like you to identify and describe what, if anything, you consider gock or positive about your thotghts, feethes, practices, experiences, or any other issues that are important fo you about you taorality. Below is a list of content features with examples. Look them over carefulfy and identify the most important area of positive experiences for you. Enter the code letter on the bubble sheet and describe this area of importance in your own words on the description sheet provided.

Code (A) BELIEFS: The infuence that your moral beliefs bave on your life,

- concider myself a moral person

- hy moral values make me proud.

Code (B) MEANING/DIRECTION:Implications that you morality bas on the guality of your life.

- When live up to my moral standards 1 feel fulfilled

- My moral walues guide me as to what is right and wrong

Code (C) RULES AND PRACTCES: The effect that your motulity has for tegulating your life.

-I do not steal because it is immoral

l always try to do the right thing

Code (D) NO ISSUES: This is nof an issue for you

64. Go to your description shet and record your code letter and your description of the important issues.

65. How positive is this isse to you at this moment?

\begin{tabular}{|c|c|c|}
\hline Not & A little & \\
\hline Positive & Positive & Positive \\
\hline
\end{tabular}
A
B
$\mathrm{C}$
D
E

66. In general, how positive is this issue in your life?

\begin{tabular}{|c|c|}
\hline Not & A little \\
\hline Positive & Bositive \\
\hline
\end{tabular}

A

B

C

D

E 


\section{PART H: SECT TON W. W \\ Distressful Content teatures \\ (with examples)}

We would like you to identify and describe what, if anything, you consider distressful or troublesome about your thoughts, feelings, practices, experiences, or any other issues that are important to you about your morality. Below is a list of content features with examples. Look them over carefally and identify the most important area of distressful experiences for you. Enter the code letter on the bubble sheet and describe this ares of inmortance in you own words on the description sheet provided.

Code (A) BELIEFS: The influence that your moral beliefs have on your life.

-Sometimer $I$ do things that go against my noral behiefs

-1 am uncertain about my moral beliefs

Code (B)MEANING/DIRECTION:Implications that your morality has on the quality of your

life.

It is difficult to guide my life consistent with my moral standards.

t am not sure about the role morality should play in my life.

Cade (C) RULES AND PRACTICES: The effect that your morality has for tegulating your life. -It is difficult to live with people who do not have similar morat standards as me It is difficult to live up to my moral rules

Code (D) NOISSUES: This is not an issue for you

67. Go to you description sheat and record your code tetter and your description of the innortant issues.

68. How distressful is this issue to you at this moment?

Not

A little

Distressful

Distressful

Distressful

B

$\mathrm{C}$

Very
Distressful
$\quad$ D

mely

Distressful

E

69. In general, how distressful is this issue in your life?

$\begin{array}{llccc}\text { Not } & \text { A little } & & \text { Very } & \text { Extremely } \\ \text { Distressful } & \text { Distressful } & \text { Distressful } & \text { Distressful } & \text { Distressful } \\ \text { A } & \text { B } & \text { C } & \text { D } & \text { E }\end{array}$

70. Have you had distress about this issue for longer than thtee months?
(A) Yes
(B) No

71. Have you had distress about this issue which signifeantly inferfered with your daily living?
(A) Yes
(B) No

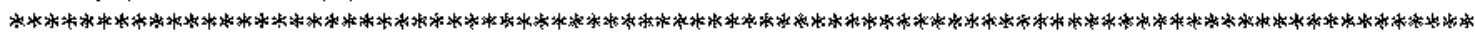

72. Of the following statements, which best describes your current thoughts and feelings with respect to moral issues:

(A). I fand myself discussing and evaluating my moral issues and values but thave not yet found an accoptable viewpoint.

(B). I am not sure about my monal values and I bave not spent mach time questioning or thinking about it.

(C). After a lot of self-examination and experience, 1 have established a clear sense of the morat guidelines in which to live my life.

(O). 1 have never really questioned my moral values because l have always known what 1 believed to be right and wrong. 


\section{Part 1 asks about political issues. \\ PART I: SECTION I}

\section{Posidive Content Ratures \\ (wih examples)}

We would like you to identify and describe what, if anything, you consider good or positive about your thoughts, feeings, practices, experiences, or any other issues that are important to you about your political issues. Below is a that of content features with examples. Look them over carefully and identify the most important area of positive experiences for you. Enter the cole letter on the bubble sheet and describe this area of irmportance in your own worts on the description sheet provided.

Code (A) BELIEFs: The influence that your political beliefs have on your life. -my political beliefs make me feel proud

-I am open ro different viewpoins

Code (B)MEANINGIDIRECTHON: Implications that your political beliefs has on the quality of your life.

I feat my political beliefs help me to gudde my life

I always try to wote in accordance with my political views

Code (C) RULES AND PRACTICES: The effect that your political beliefs has for regulating your life.

-I feel privedged that I am able to vote

the the way my political leaders represent and interpret the law

Code (D) NO ISSUES: This is not an issue for you

73. Go to your description sheet and record your code letter and your description of the important issues.

74. How positive is this issue to you at this moment?

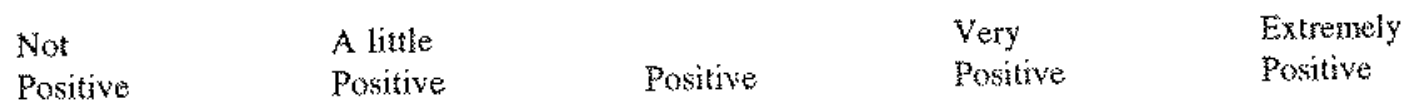
A.
$\mathrm{B}$
$\mathrm{C}$
$\mathrm{D}$
$\mathrm{E}$

75. In general, how positive is this issue in your life?

$\begin{array}{lcccc}\text { Not } & \text { A littie } & & \text { Very } & \text { Extremely } \\ \text { Positive } & \text { Positive } & \text { Positive } & \text { Positive } & \text { Positive } \\ \text { A } & \text { B } & \text { C } & \text { D } & \text { E }\end{array}$




\section{PART I: SECTION II \\ Distressful Comtent teaturas \\ (with examples)}

We would like you to didentify and describe what, if anything, you consider distressful or troublesome about your thoughts, feelings, practices, experiences, or any otber issues that are important to you about your political issues. Below is a list of content features with examples. Look them over carefully and identify the most important area of distressful experiences for you. Enter the code letter on the bubble sheet and describe this area of importance in your own words on the description sheet provided.

Code (A) BEELEFS: The infuence that your political beliefs have on your Ife.

I am confuset about my ideas on politiss

I an not sure what political platform 1 believe in

Code (B) MEANING/DIRECTION: Implications that your political belisfs has on the quality of your life.

-It if difficult to guide my life through my political beliess

+1 am not sure how my political orientation will fis into my family sinucture

Code (C) RULES AND PRACTCES: The effect that your political beliefs bas for regulating your life.

-Sone political decisions, sach as war and government comrol, upset me

-It upsers me when politicians take advantage of their power and manipulate the law

Code (D) NO ISSUEs: This is not an issue for you

76. Go to your description sheet and record your code letter and your description of the importan issues.

77. How distressful is this issue to you at this moment?

$\begin{array}{ccccc}\text { Not } & \text { A litule } & \text { Very } & \text { EExtremely } \\ \text { Distressful } & \text { Distressful } & \text { Distressful } & \text { Distressful } & \text { Distressful } \\ \text { A } & \text { B } & \text { C } & \text { D } & \text { E }\end{array}$

78. In general, how distressful is this issue in your life?

$\begin{array}{llccc}\text { Not } & \text { A little } & & \text { Very } & \text { Extremely } \\ \text { Distressfut } & \text { Distressful } & \text { Distressful } & \text { Distressful } & \text { Distressful } \\ \text { A } & \text { B } & \text { C } & \text { D } & \text { E }\end{array}$

79. Have you had distress about this issue for longer than three months?
(A) $\mathrm{Yes}$
(B) No

80. Have you had distress about this issue which significantly interfered with your daily living?
(A) Yes
(B) $\mathrm{No}$

81. Of the following statements, which best describes your cumrent thotghis and fedings with respect to political issues:

(A). I am not sure about my political orientation and I have not spent nuch time questioning or thinking about it.

(B). I find myself discussing and evaluating my political ideas but I bave not yet found an acceptable viewpoint.

(C). I tave never really questioned my political beliefs becalse thave always known what I believed to ybe right and wrong.

(D). After a lot of self-xamination and experience, I have established a clear sense of the political guidelines in which to live my life. 
APPENDIX $\mathrm{C}$ 


\title{
LEADER'S MANUAL
}

\section{for}

\author{
Making Life Choices
}

\section{Work Shop}

(DRAFT)

This Manual was developed for the Making Life Choices Workshop at the Laboratory for Research on Psychosocial Development and Behavior, Department of Psychology, Florida International University, Miami, Florida, 33199. The materials were developed by Steven L. Berman, Alan M. Berman, Laura Ferrer and William M. Kurtines. Any comments or suggestions regarding the material should be directed to authors at the above address.

Revised: 3/1/95

Printed: April 17, 1996 
WORKSHOP PROCEDURAL OUTLINE 
Session 1: (approximately $1 \mathrm{hr} .30 \mathrm{~min}$ )

1. Set up video tape.

(Inform subjects that they are being video taped but the tapes are only for our own feedback and they are strictly confidential.)

2. Collect completed workbooks. (They may keep the study guides.)

\section{Introductions.}

(Begin with yourself. Say your name and a little personal background, then ask each subject to do the same.)

\section{Review session structure.}

- Ist session: review study guide material, steps to problem solving and decision making, practice using those skills on the hypothetical dilemma mentioned in the workbook

-2nd session: practice using problem solving and decision making skills on your own personat dilemmas.

-3rd session: follow up on personal dilemmas.

-4th session: practice using skills on new dilemmas.

-5th session: follow up and closure.

\section{Talk about workshop's purpose.}

(We will not make decisions for you; our focus is on developing your critical skills as a way to help you make difficult life choices)

\section{Review basic concepts from the Study Guide}

(Instead of lecturing have each subject answer questions such as: What is a life choice? What do we mean by responsibility?)

(Use Poster Charts in room and/or detailed outline)

\section{Grp Exercise 1: Discuss Hypothetical Dilemma (from Workbook)}

What should he do?, Why?, Use ICE, positively reinforce any critical statements)

(Everyone should participate; They do most of the talking - you facilitate!)

\section{A. Role play}

(Have them play "devil's advocate" - argue against their own opinions) 
Session 2: (approximately $1 \mathrm{hr}, 30 \mathrm{~min}$ )

\section{Set up video tape.}

2. Review workshop's purpose.

(We will not make decisions for you; our focus is on developing your critical skills as a way to help you make difficult life choices)

3. Review basic concepts from the Study Guide

(Instead of lecturing have each subject answer questions such as: What is a life choice? What do we mean by responsibility?)

(Follow the outline on the Poster Charts [Appendix Al in the room and/or use the outline in Appendix B for assistance.)

\section{Grp Exercise 2: Discuss Real Personal Life Choice Dilenmas}

A. Discuss ground rules for group exercise

(See Poster Charts or Appendix A)

B. Discuss individual's role

(See Poster Charts or Appendix A)

C. Discuss group's role

(See Poster Chants or Appendix A)

D. Discuss each person's life choice dilemma

(Use ICE, positively reinforce any critical statements)

(Everyone should participate; They do most of the talking - you facilitate!)

(Spend equal time on everyone's dilemma; You do not have to complete the discussion or solve the problem during this session)

\section{E. Role Playing - - perspective taking}

(Have them play "devil's advocate" - argue against their own opinions, and/or have other menbers of group adwocate for different perspectives) 
Session 3: (approximately $1 \mathrm{hr}, 30 \mathrm{~min}$.)

1. Set up video tape.

2. Review workshop's purpose.

We will not make decisions for you; our focus is on developing your critical skills as a way to help you make difficult life choices)

\section{Review basic concepts from the Study Guide}

(Instead of lecturing have each subject answer questions such as: What is a life choice? What do we mean by responsibility?)

(Use Poster Charts [Appendix A] and/or outline in Appendix B for assistance.)

\section{Follow up on each person's life choice dilemma}

(Use ICE, positively reinforce any critical statements)

Everyone should participate; They do most of the talking - you facilitate!)

(Spend equal time on everyone's dilemma; You do not have to complete the discussion or solve the problem during this session)

\section{A. Role Playing -- perspective taking}

Have them play "devil's adwocate" - argue against their own opinions, and /or have other members of group advocate for different perspectives)

\section{Homework - Think of a new dilemma}

(Explain that these skills need to be used in all areas of your life, not just on one dilemma. Therefore, next time we will be discussing a new dilemma of your choice.)

(Encourage them to choose a dilenma from a different domain Fi.e. personal development, interpersonal development, world view] of the IDS. If they have difficulty moving to a new domain, at least encourage them to use a different content area within the domain [see the IDS7). 
Session 4: (approximately $1 \mathrm{hr}, 30 \mathrm{~min}$ )

1. Set up video tape.

2. Review workshop's purpose.

We will not make decisions for you; our focus is on developing your critical skills as a way to help you make difficult life choices)

\section{Review basic concepts from the Study Guide}

(Instead of lecturing have each subject answer questions such as: What is a life choice? What do we mean by responsibility?)

(Follow the outline on the Poster Charts (Appendix Al in the room andior use the outline in Appendix $B$ for assistance.)

\section{Grp Exercise 2 (cont): Discuss Another Real Personal Life Choice Dilemmas}

A. Discuss each person's life choice dilemma

(Use ICE, positively reinforce any critical statements)

(Everyone should participate; They do most of the talking - you facilitate!)

(Spend equal time on everyone's dilemma; You do not have to complete the discussion or solve the problem during this session)

E. Role Playing - perspective taking

(Have them play "devil's advocate" - argue against their own opinions, and/or have other members of group advocate for different perspectives) 
Session 5: (approximately i hr. $30 \mathrm{~min}$.)

\section{Set up video tape.}

2. Review workshop's purpose.

We will not make decisions for you; our focus is on developing your critical skills as a way to help you make difficult life choices)

\section{Review basic concepts from the Study Guide}

Instead of lecturing have each subject answer questions such as: What is a life choice? What do we mean by responsibility?)

(Use Poster Charts [Appendix A] and/or outline in Appendix B for assistance.)

\section{Follow up on each person's life choice dilemma}

(Use ICE, positively reinforce any critical statements)

(Everyone should participate; They do most of the talking - you facilitate!)

(Spend equal time on everyone's dilemma; You do not have to complete the discussion or solve the problem during this session)

\section{A. Role Playing -- perspective taking}

(Have them play "devil's advocate" - argue against their own opinions, and/or have other members of group advocate for different perspectives)

\section{Closure and termination}

\section{A. Action and personal responsibility}

(Now you have all these things to consider but it is your own personal decision to make. Need for follow through.)

\section{B. Maintenance}

(if these skills are not practiced they will be lost)

6. Set up individual post assessment appointments 


\section{POSTER BOARDS}




\section{Basic Concepts}

I. Life Choices

II. Human responsibility

III. Solving problems with ICE
A. 1
B. C
C. $\mathrm{E}$

IV. Beyond ICE: using critical decision making and problem solving skills in making life choices

A. What does critical mean?

1. Adopting a critical stance

a. suspend judgment

b. critical examination

(1) self-deception

B. Critical thinking and critical discussion 
Group Exercise 1: Warm-up

Discussion of Hypothetical Life Choices

I. What should the young man do? Why? 
Group Exercise 2: The Real Thing

Discussion of Personal Life Choice

I. Ground rules for group exercise
A. No "put downs"
B. Everyone participates
C. No side talk
D. Confidentiality

II. Group discussion of personal life choice:

A. Individual's role

1. Individual takes responsibility for presenting personal life dilemma

2. Individual uses critical decision making and problem solving

3. Individual is responsible for eliciting feedback

B. Group's role

1. Group helps to identity problem, issues, choices, etc.

2. Group helps to generate alternatives

3. Group challenges, questions, etc.

4. Group provides constructive feedback and positive reinforcement for these activities

5. Group provides empathy and support

C. Role Playing -- perspective taking 


\section{BASIC CONCEPTS OUTLINE}




\section{Basic Concepts Outhine}

1. Life choices

A life choice is a choice or decision that an individual makes that affects the quality of hisher life and or the lives of others.)

\section{Human responsibility}

(One of the most important things that we want you to leam in this workshop is that human being make decisions that affect the quality of their lives and they are responsible for those decisions - that you cannot even choose not to choose. In this workshop we want you to learn better ways for making these decisions or choices. However, in the end you are the one who is responsible for those choice.)

\section{Solving problems with ICE}

\section{A. Standard problem solving strategies}

(steps don't always go in order)

\section{I: Identify problem}

(recognizing that a problem exists and defining the problem, i.e. an addict might not admit to having a problem, or you think you have a problem of which classes to take but your real problem is that you do not know what you want to do with your life)

\section{2. $\mathrm{C}_{*}^{*}$ Create alternatives}

(Be creative; more alternatives increase chances for good solution)

\section{E: Evaluate alternatives}

(evaluating the alternatives and selecting the best solution) 
IV. Beyond ICE: using critical decision making and problen solving skills in making life choices

(what we add to the basic problem solving steps is a critical dimension)

\section{A. What does critical mean?}

(goes beyond ordinary problem solving; critical = skeptical, challenging, questioning)

1. Adopting a critical stance

a. suspend judgment (entertaimment)

fbeing able to step back; consider all options fully, reject nothing initially)

b. critical examination (challenge)

(objectively evaluate all alternatives including your own goals, choices and preconceptions)

B. Critical thinking and critical discussion

(we need critical discussion because if we just think critically alone, it is still easy to fool oneself)

a. self-deception

(can avoid by opening up your own choices to critical examination with other affected and neutral parties; other people can bring different perspectives to the problem and suggest alternatives not previously considered.) 
May 27,1958

1980

1983

1987

$1988-1989$

$1989-1991$

$1992-1995$

1992-Present
Born, Saugus, Massachusetts

B.S., Psychology

MCGill University

Montreal, Canada

M.A., Educational Esychology

MeGill University

Montreal, Canada

M.S., Clinical Psychology

Nova university

Ft. Lauderdale, FIorida

Xouth \& Family Counselor

Youth Service Bureau

West Palm Beach, Florida

outreach Program Director

YMCA of Greater Miami.

Miami, Florida

Lab Director

Psychosocial Behavior \& Development Lab Florida International university Miami, Florida

Teaching Associate

Florida International University Miami, Florida

\section{PUBLICATIONS AND PRESENTATIONS}

Berman, S., Kuxtines, W., Silverman, W. \& Ramos, I. (1996). The impact of exposure to crime and violence on urban youth. Accepted for publication in Ihe American Journal of orthopsychiatry.

Kurtines, W.M., \& Berman, S.L. (1995). Moral development and education today and tomorrow. Moral Education Forum, 20, $16-23$.

Berman, S., Wanderman, J., Briones, E., Wolf, L., \& Kurtines, W. (1993). Education for democracy: A coconstructivist perspective. Theory of Education, 5. 8796. 